\title{
Nucleation of solid solutions crystallizing from aqueous solutions
}

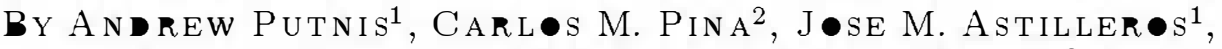 \\ LURDES FERNÁNDEZ-Día $\mathbf{Z}^{2}$ AND MANUEL PRIET ${ }^{3}$ \\ ${ }^{1}$ Institut für Mineralogie, University of Münster, \\ Correnstrasse 24, 48149 Münster, Germany \\ 2 Departamento de Cristalografía y Mineralogía, \\ Universidad Complutense de Madrid, 28040 Madrid, Spain \\ ${ }^{3}$ Departamento de Geología, Universidad de Oviedo, 33005 Oviedo, Spain
}

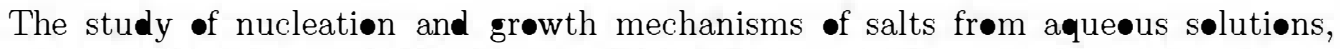
as a function of supersaturation, is described using both macroscopic and micr-

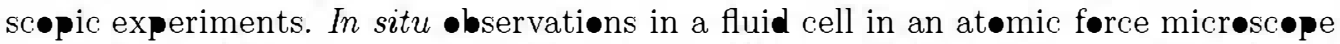

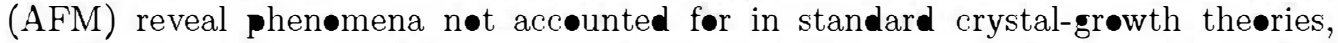
specifically $\bullet$ the role of the crystal structure of the substrate in cøntrolling spiral

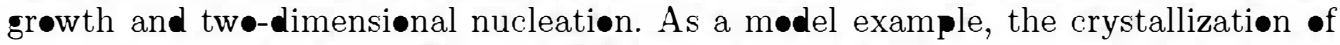

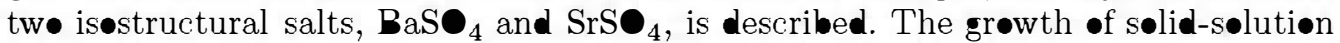

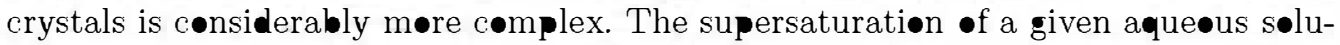

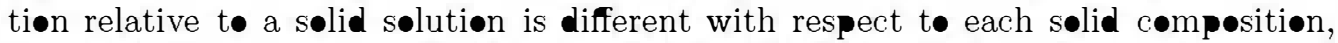

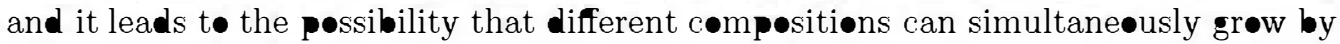

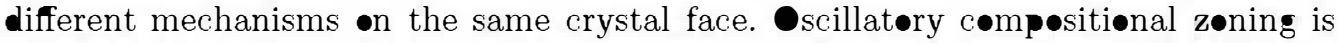
an ther consequence of the interplay between the thermøynamics and the kinetics

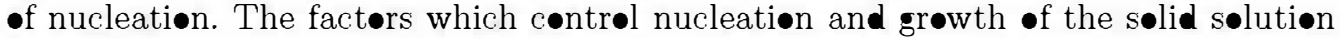
$(\mathbf{B a}, \mathrm{Sr}) \mathrm{S}_{4}$ frøm an aque us sølutiøn are described. The predictiøns made frøm the thery are compare with direct $\bullet$ bservatiøns $\bullet$ crystal growth in an AFM.

Keywords: solid solutions; crystallization; two-dimensional nucleation; spiral growth; atomic force microscopy

\section{Intrøductiøn}

The crystallizatiøn of salts frøm aqueus søutiøns has been the subject of research før many years, and the fundamental ideas are generally well understøod (e.g.

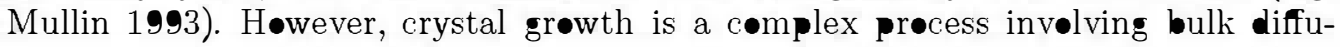
siøn through the fluid, surface adsørption and diffusion and finally the integration

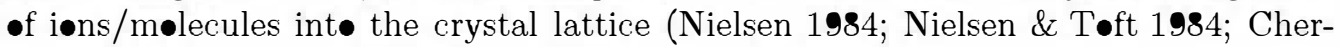

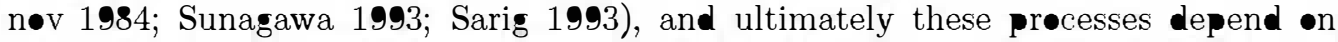
the reactivity of the crystal surface as well as the saturation state of the fluid.

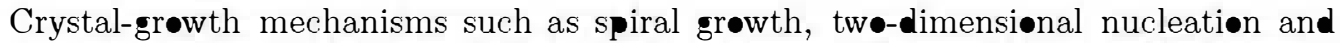

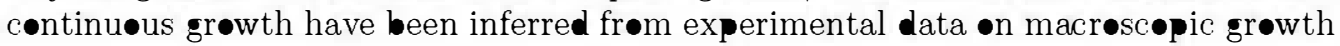


rates as a function of increasing fluid supersaturation (Sunagawa 1984, 1987, 1993), althøugh understanding the critical supersaturatiøn values for each mechanism is complicated by many factors that can influence the actual supersaturation at which nucleation eccurs.

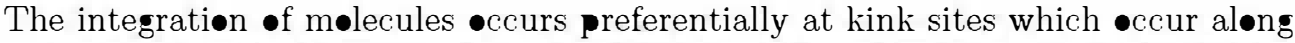

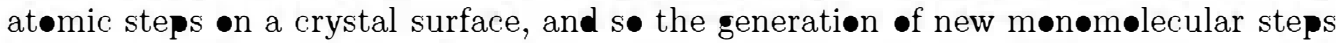
is important for understanding the verall crystal-growth rate. With in situ crystal-

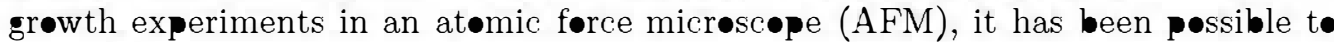

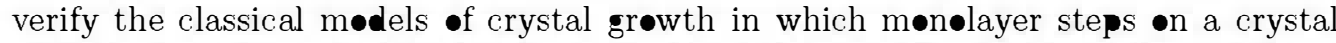
surface are generate either by the presence of screw disløcations, resulting in spiral

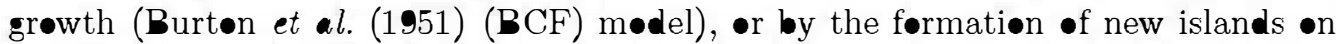

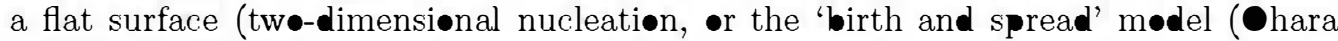
\& Reid 1973)). It is generally assumed that bulk crystal-growth rate is controlle by spiral growth at low supersaturations and by surface nucleation at higher supersaturatiøns (Sunagawa 1993). This paper investigates these tw mechanisms in relation

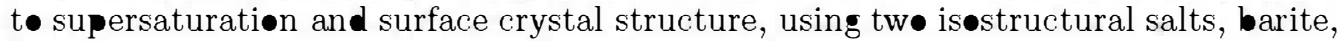
$\mathrm{BaS}_{4}$, and celestite, $\mathrm{SrS}_{4}$, as mødel examples.

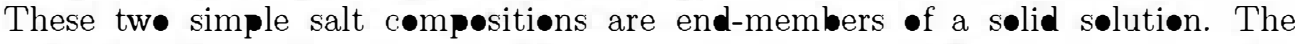

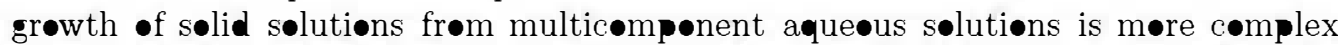
than that of pure end-members and is poorly understøod. Only relatively recently have there been significant advances in understanding the thermedynamics of such sølid-sølution-aque us-sølution (SS-AS) systems (Lippmann 1980, 1982; Glynn \&

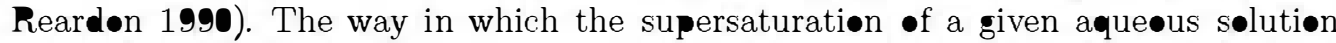

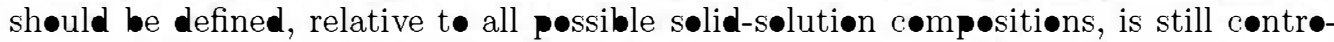

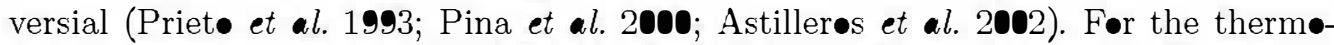
dynamic representation of SS-AS systems, the mixing properties of the sølid sølution

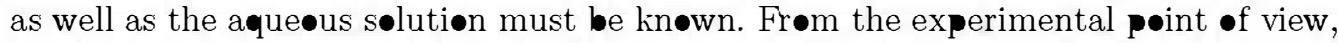
it is als• difficult to separate thermøynamic and kinetic effects in crystal-growth experiments.

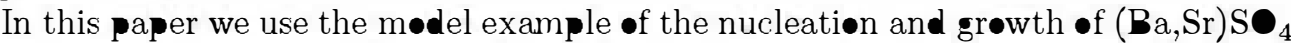
frøm aque solution. The sølid sølution is assumed tø approximately ideal

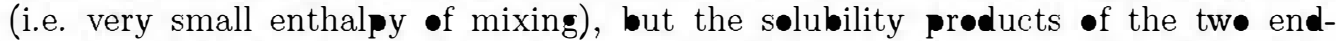
members differ by three orders of magnitude. Althøugh the degree $\bullet$ ideality $\bullet$ the $(\mathbf{B a}, \mathrm{Sr}) \mathrm{SO}_{4}$ sølid sølution has been widely discussed (e.g. Becker et al. 2000), the main controlling factor of its nucleation and growth behaviøur is the large difference in sølubility of the end-members. Such a situatiøn is nøt unusual and has important

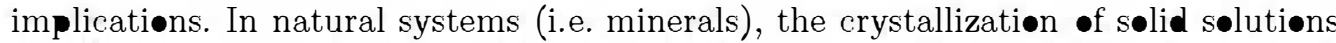
frøm aqueus sølutions is the n॰rm, and our ultimate aim here is to understand

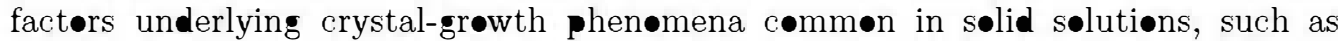

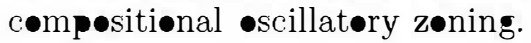

\section{Experiment}

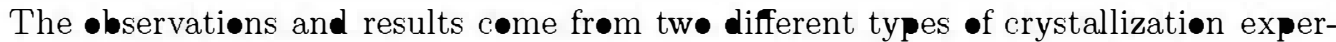
iments. In the first, crystallization takes place by the counter-diffusion of reactants through a column of porøs silica hydrogel. In such an experiment, nucleation is suppressed and takes place at relatively high supersaturation (Henisch 1989). The

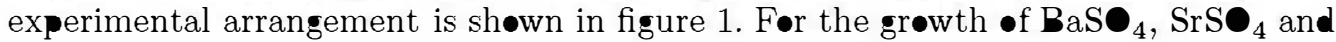




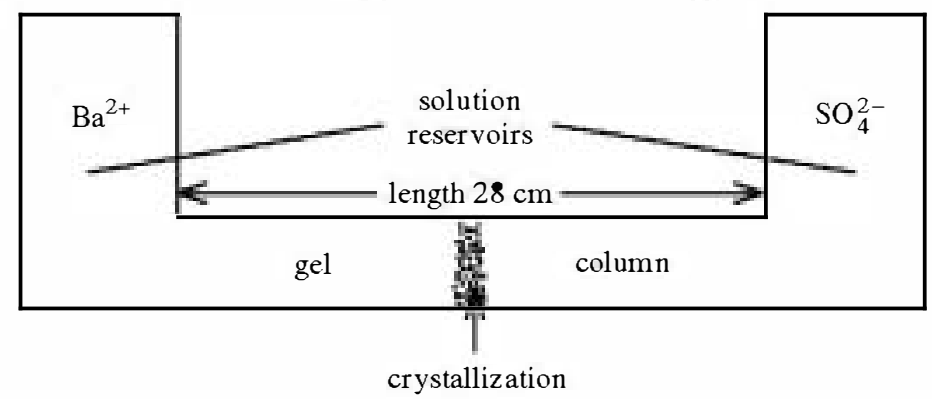

Figure 1. Schematic of the experimental arrangement for crystal growth by

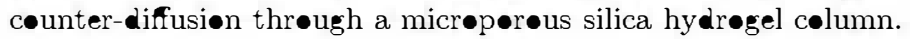

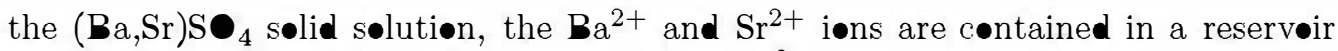

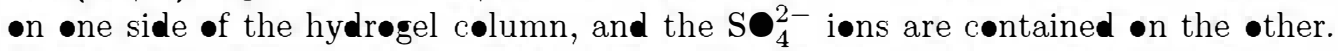
Counter-diffusion results in eventual crystallization near the centre of the column.

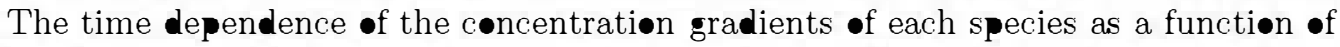
starting concentration in the reservoirs has been predetermined. The supersatura-

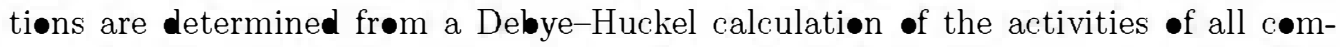
pønents. Thus, nucleation takes place under contrøle conditions of supersaturatiøn and supersaturation rate (Priet• et al. 1990, 1991, 1994). This second factor is very important and is discusse further below.

In the secød type of experiment, nucleation and growth were studied directly

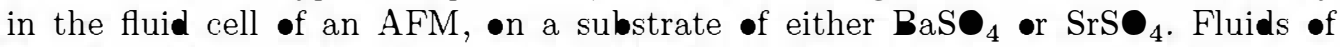
varying supersaturatiøns were passed ver the substrate and precesses such as step

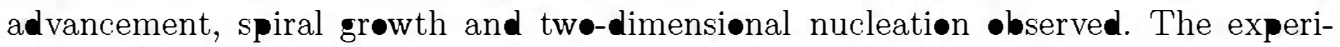
mental details can be found in Bosbach et al. (1998), Pina et al. (2000) and Risthaus et al. (2001).

\section{Crystal grøwth of the pure end-members $\mathrm{BaSO}_{4}$ and $\mathrm{SrSO}_{4}$}

\section{(a) Macroscopic growth experiments}

The principal result frøm experiments involving the counter-diffusion of species through an inert hydregel transport medium is that the supersaturation at which nucleation takes place is highly dependent on the starting conditions, i.e. the initial concentration of the reactants in the reservoirs. The higher the concentratiøns in the reservirs, the faster the rate of change of supersaturatiøn thrøugh-ut the column, and the higher the value of the supersaturation at which nucleation $\bullet c c u r s$. This value of supersaturation may be termed the threshold supersaturation and is a kinetic concept, determine by the rate of departure frøm equilibrium (the supersaturation rate). It is thus different frøm the concept $\bullet$ a critical supersaturation, which is essentially a thermodynamic concept ependent on the positive and negative energy terms assøciated with the formation of a critical nucleus (as in classical nucleation thery). Before outlining the experimental results, it is convenient t• review these concepts of critical and threshøld supersaturation. 
In classical hømeneus nucleation thery, the theretical nucleation rate, $J$, i.e. the number of nuclei førmed per unit volume and time, is given by (Nielsen 1964)

$$
J=\Gamma \exp \left(\frac{-\delta \sigma^{3} \Omega^{2}}{k^{3} T^{3}(\ln S)^{2}}\right)
$$

where $\delta$ is a shape factor, $\sigma$ is the nucleus-solution interfacial tension and $\Omega$ is the

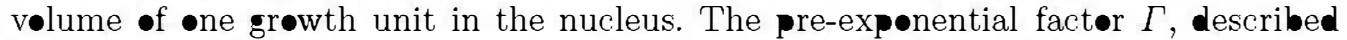

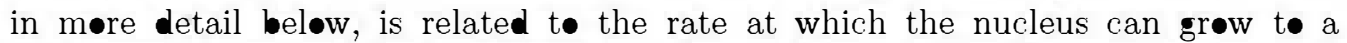
supercritical size, and hence it involves volume diffusion. $T$ is the temperature and $k$ is Boltzmann's constant. $S$ is the supersaturation rati $C / C_{\mathrm{s}}$, where $C_{\mathrm{s}}$ is the concentration of the solution in equilibrium with the crystalline phase and $C$ is the

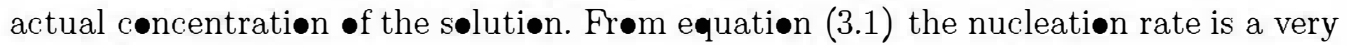
sharp function of supersaturation. It is usual t• define the critical supersaturation as that corresponding t• a nucleation rate of 1 nucleus $\mathrm{s}^{-1} \mathrm{~cm}^{-3}$.

An ther important concept in the classical thery is the relationship between the solubility and the critical supersaturatiøn. First, the interfacial tension $\sigma$ is related inversely to the søbility, sø that the higher the sølubility, the lower the surface tensiøn and the lower the critical supersaturatiøn (Söhnel 1982; Mullin 1993). Secønd,

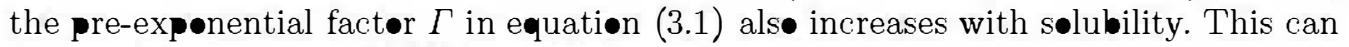
be seen by evaluating $\Gamma$ (Waltøn 1967, 1969) as

$$
\Gamma=\nu_{\bullet} N_{\bullet} A^{*} \exp \left(\frac{\Delta G_{\mathrm{v}}}{k T}\right)
$$

where $\nu_{\bullet}$ is a frequency fact $\bullet$, $A^{*}$ is the surface area $\bullet$ the critical nucleus and $\Delta G_{\mathrm{V}}$ is the activatiøn energy barrier for diffusion frøm the bulk sølutiøn to the

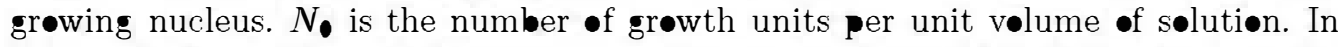

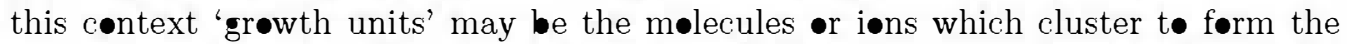
crystalline phase. In sølutiøns of sparingly søluble substances $N_{\bullet}$ is small and the grøth units are relatively distant frøm $\bullet$ ne anther.

The classical concepts ab॰ve assume that supersaturation is uniførm thrøughøut

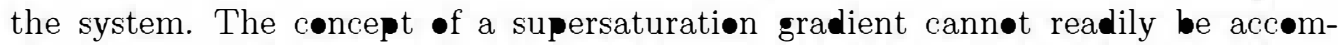

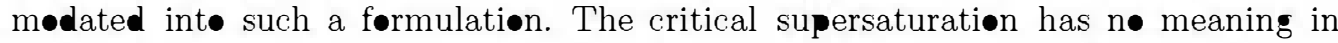
a situation where the supersaturation changes rapidly and metastable states are preserved. The maximum supersaturation or the metastability limit which can be achieved under any given set $\bullet$ conditions is a kinetic concept-the threshøld supersaturatiøn. As in all kinetic concepts, the value of the threshøld supersaturation will

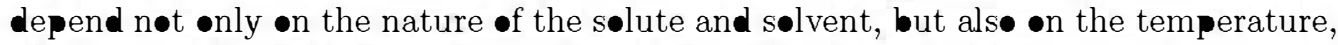
stirring and the fluid dynamics of the sølutiøn, its thermal histøry, the total mass $\bullet$ the sølutiøn, etc. (Khamskii 1969). In any experimental determinatiøn of supersaturation it is the threshøld value which is determined, unless the assumptions of the classical theory can be shown t• apply. The threshøld supersaturation is the relevant concept whenever supersaturation gradients exist. Similarly, the time taken t• førm nuclei depends •n supersaturation gradients. This 'waiting time' is therefore different frøm the 'incubation time' for nucleation, which is a concept relate to crystallizatiøn under uniform conditions. 


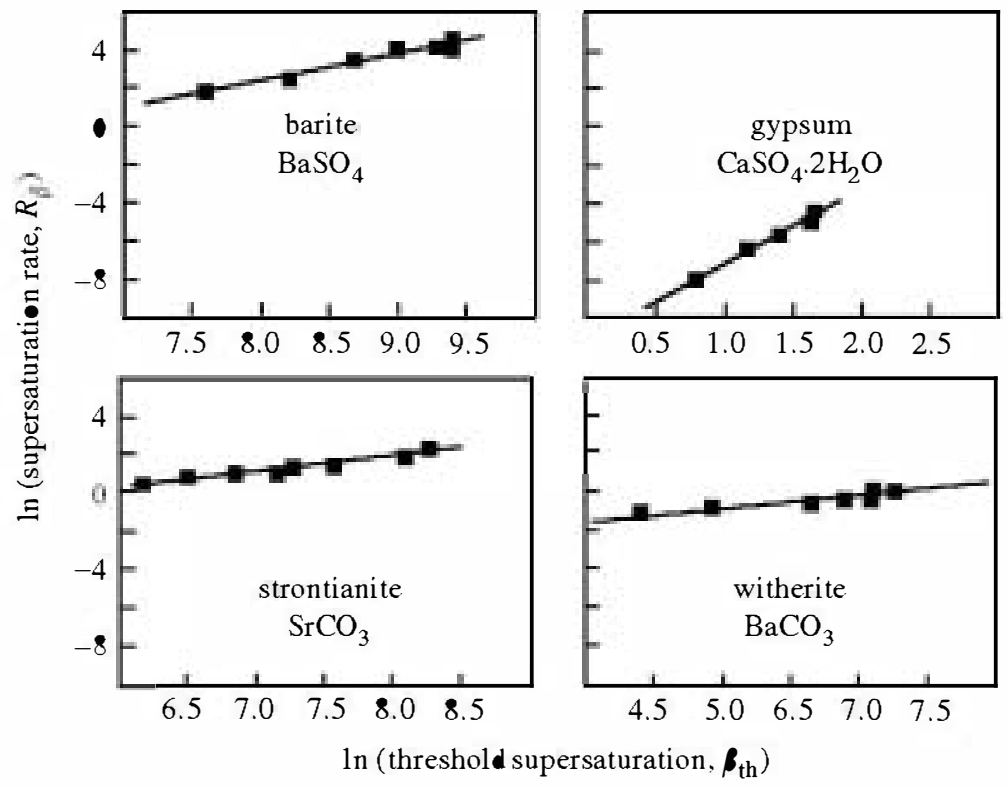

Figure 2. The correlation between the threshøld supersaturation $\boldsymbol{\beta}_{\mathrm{th}}$ and the supersaturation rate $R_{\boldsymbol{\beta}}$ as a linear pløt of $\ln \boldsymbol{\beta}_{\mathrm{th}}$ against $\ln R_{\boldsymbol{\beta}}$.

(b) Experimental results

In all cases studied (Putnis et al. 1995) there is an empirical relatiønship between the supersaturation rate, $R_{\boldsymbol{\beta}}$, and the threshøld supersaturation $\boldsymbol{\beta}_{\text {th }}$ given by

$$
R_{\beta}=K\left(\beta_{\mathrm{th}}\right)^{m}
$$

where $K$ and $m$ are empirical cefficients (figure 2). The relationship between thresh-ld supersaturation and supersaturation rate applies t• a range of substances with

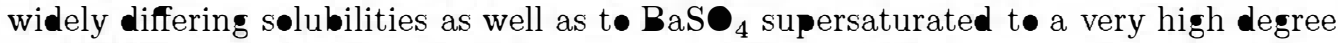
by inhibitors, suggesting that the values of the empirical parameters $K$ and $m$

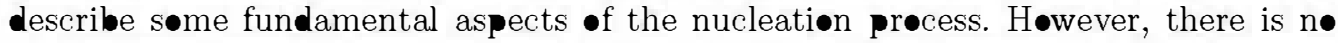

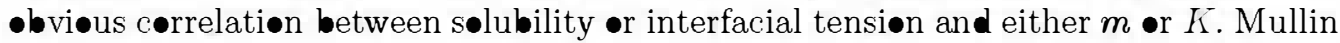

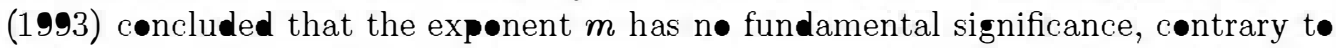
earlier suggestiøns relating it t• the number of elementary species invelved in the nucleation process.

Equatiøn (3.3) als• applies in cases where the rate of change of supersaturation

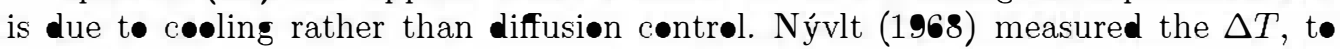

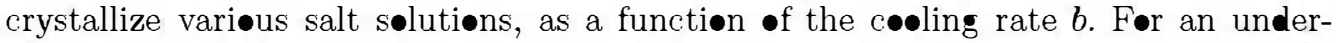
cœling $\Delta T$, the supersaturation was define as the maximum absolute supersaturation $\Delta C_{\max }=C-C_{\mathrm{s}}$, where $C_{\mathrm{s}}$ is the equilibrium concentration $\bullet$ the salt at crystallizatiøn temperature and $C$ is the actual concentratiøn used. The temperature dependence of the equilibrium concentration is given by $\mathbf{d} C_{\mathrm{s}} / \mathbf{d} T$. Nývlt f•und that før aqueus sølutions of møre than 25 substances the data could be fitted the equation

$$
\frac{\mathbf{d} C_{\mathrm{s}}}{\mathbf{d} T} b=K\left(\Delta C_{\max }\right)^{n}
$$



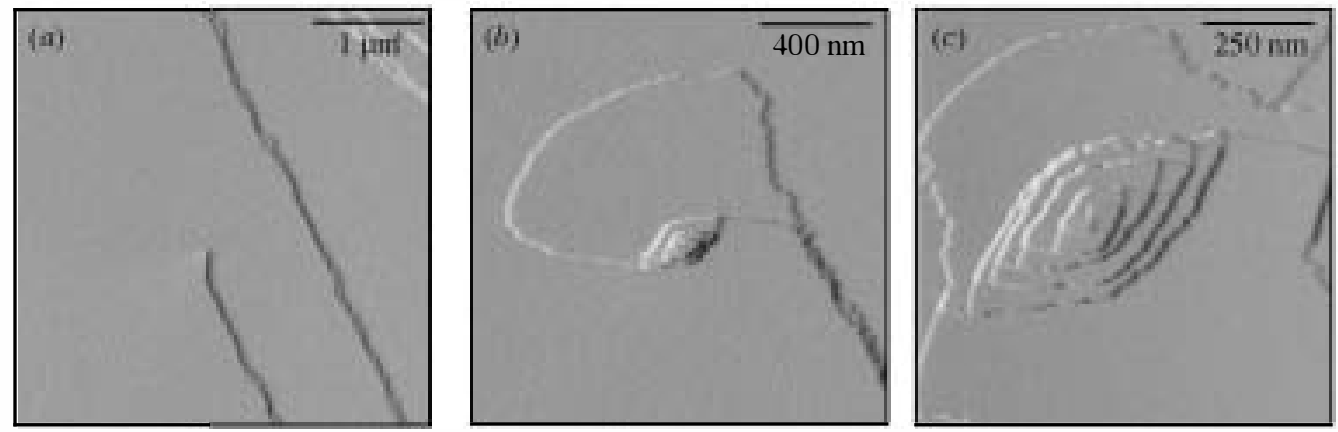

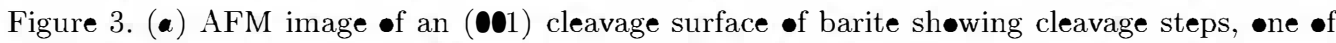
which terminates at a screw dislecation core. Deiønized water that is passed through the fluid cell slightly dissølves the step edges, separating the tw $\bullet \mathrm{BaSO}_{4}$ layers in each step. (b) With

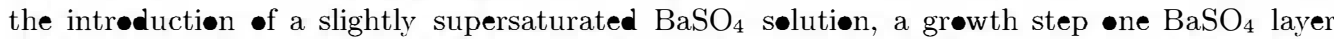

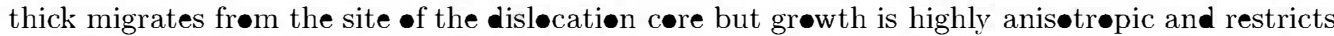

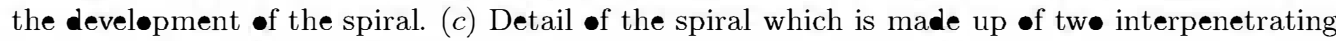
spirals made of alternate $\mathrm{BaSO}_{4}$ layers.

It is clear that $R_{\beta}$ in equation (3.3) controls $\boldsymbol{\beta}_{\text {th }}$ in the same way that $\boldsymbol{b}$ controls $\Delta C_{\max }$ in equation (3.4).

The values of threshøld supersaturation for $\mathbf{B a S O}_{4}$ and $\mathrm{SrSO}_{4}$ reflect the large difference in sølubility of these salts. The sølubilities, expressed as the løgarithm of the sølubility prøduct at equilibrium, løg $K_{\mathrm{sp}}$, are $\mathbf{- 9 . 9 6}$ for $\mathbf{B a S O}$ and $\mathbf{- 6 . 6 2}$ for $\mathrm{SrSO}_{4}$ (Bløunt 1977; Reardøn \& Armstrøng 1987). Threshøld supersaturation for nucleation under the same experimental conditions is typically tw orders of magnitude higher for barite than celestite. Før example, for given starting concentrations - f the reservoir sølutions and a specific experimental design (i.e. diffusion length in the column, porosity of the silica gel, etc.) the threshøld supersaturation for barite is $1.2 \times 10^{4}$ compared with $1.3 \times 10^{2}$ for celestite (Priet• et al. 1993). These overall high values are due te crystallization in a gel. In a free sølution, where mass transport can take place by convectiøn, such large departures frøm equilibrium are nøt achievable. This is addressed in the next set of experiments. The large difference in threshøld supersaturation has important implications when considering the crystallizatiøn of SS-AS systems.

\section{Crystal-growth experiments in a fluid cell in an AFM}

Both $\mathrm{BaSO}_{4}$ and $\mathrm{SrSO}_{4}$ crystals have perfect cleavage on (001) and flat faces can be easily prepared as substrates for in situ crystal-growth experiments. Aqueøs sølutiøns with knøwn supersaturation were used t• determine the range of supersaturations where crystal growth takes place by step advancement, and the critical value at which two-dimensional nucleation occurs. These cleaved surfaces have many cleavage steps, as well as points of intersection with screw dislocation lines prøviding step edges and sites for spiral growth. Figure 3 shøws a crystal-growth sequence where a nuid containing $\mathbf{B a}^{2+}$ and $\mathrm{SO}_{1}^{2-}$ ions at a supersaturation value of 12 is

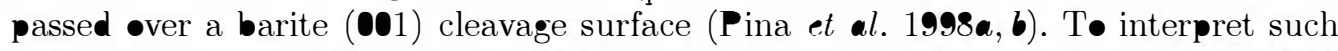

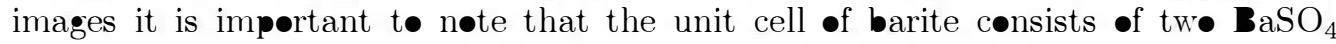



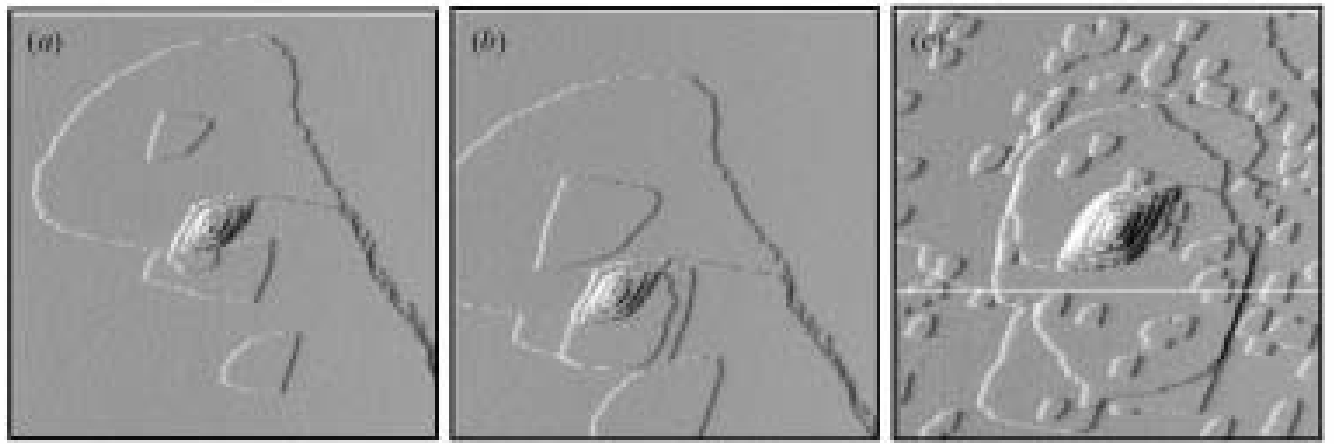

Figure 4. ( ) AFM image of an (001) cleavage surface shøing in situ tw-dimensiønal nucleatiøn.

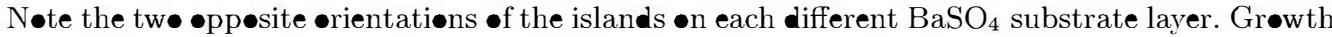

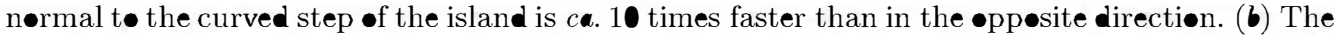
spiral can only spread when underpinned by one of the spreading islands. (c) Increasing the supersaturation greatly increases the nucleation rate. The image area in each case is $2 \mu \mathrm{m} \times 2 \mu \mathrm{m}$.

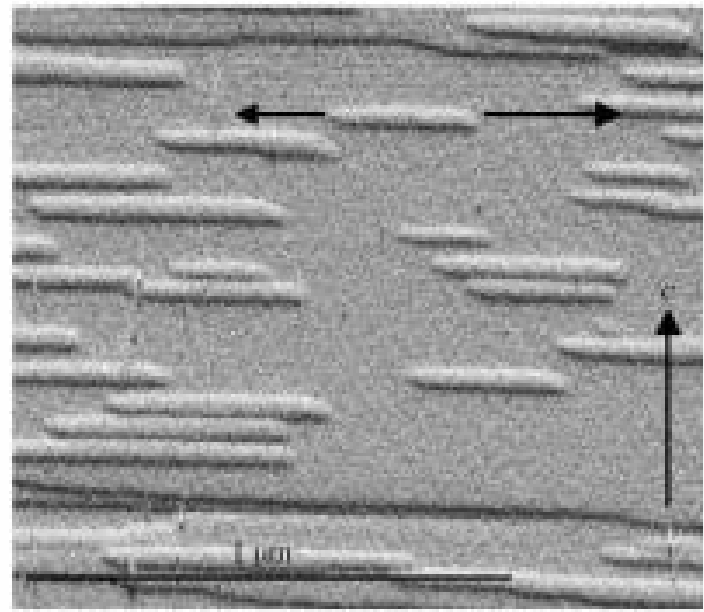

Figure 5. Twø-dimensiønal nucleation on a (210) surface of barite. Islands grøw as needles, -ne $\mathrm{BaSO}_{4}$ layer thick, preferentially aløng the $\langle 120\rangle$ directiøn, shøwn by the lønger arr $\bullet$.

layers parallel t• $(\mathbf{0} 1)$, and that each layer is related by a $2_{1}$ screw-axis parallel t• the $c$-axis.

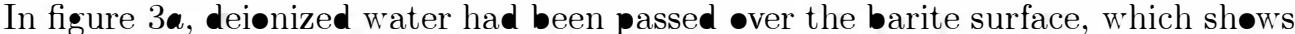
tw cleavage steps, one terminated at a screw dislocation. Each cleavage step is $7.2 \AA$

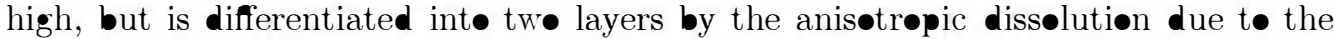

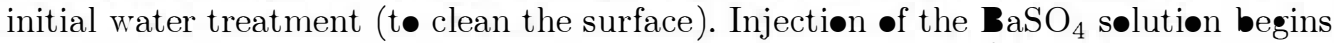
step grøth, with new steps being $\bullet \mathrm{BaSO}_{4}$ layer thick $(3.6 \AA)$. The cleavage steps migrate normal to their length, and spiral growth begins at the dislocation core.

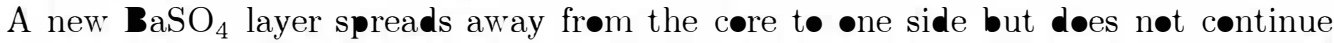
arøund the spiral as in classical descriptions of spiral grøth (figure 36). Instead, the spiral becomes increasingly tightly wound arøund the core with very little lateral grøth (figure $3 c$ ), due to the marked anisotropy of the grøth rate within such

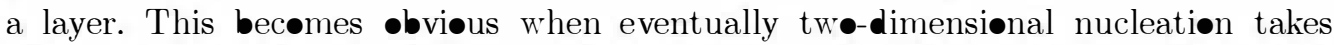
place $\bullet$ the surface, with islands having a sectør-shaped morphøløy (figure 4a). 


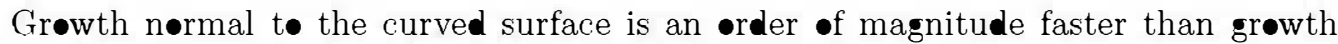

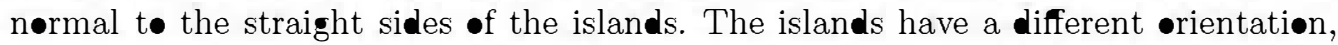

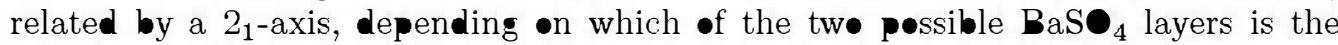
substrate. The anisøtrøy is a structurally induced self-inhibitør for spiral grøwth.

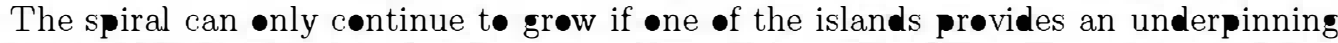
-ver which the fast-growing layer can grow (figure $4 b$ ). When the supersaturation -f the fluid is increased, the nucleation rate increases significantly (figure 4c) and reaches a catastrophic rate as the supersaturation is increase yet further.

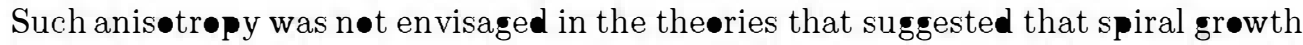

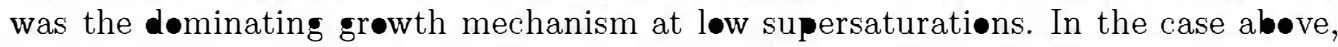

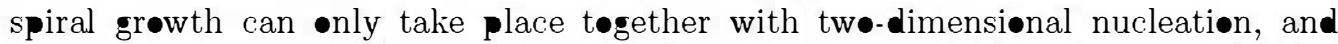

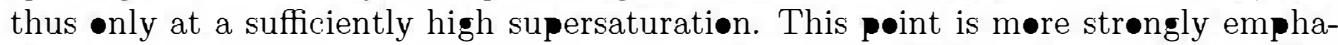
sized when considering nucleatiøn and grøth $\bullet$ the $(210)$ surface of barite. The

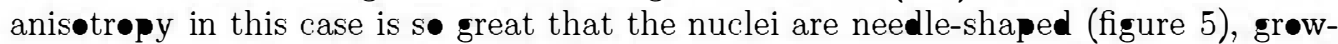

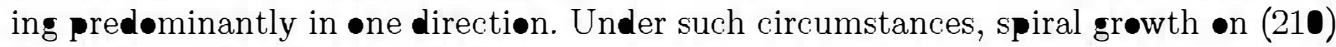
is not considered a possibility.

Frøm these measurements it is pøssible t• determine the transitiønal supersatura-

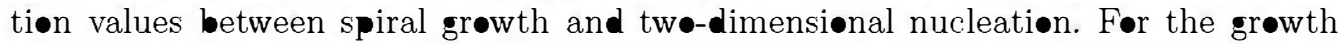
-f pure $\mathrm{BaSO}_{4}$ on a $\mathrm{BaSO}_{4}(\mathbf{0 0 1})$ substrate this value is 7.0. For the equivalent case $\bullet$ nucleation of $\mathrm{SrSO}_{4} \bullet n$ a $(\mathbf{0 0 1})$ celestite surface, it is 2.3 (Pina et al. 2000).

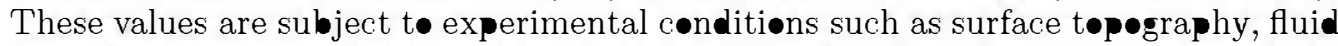
fløw rate, temperature and the orientation of the face, but før the purposes of the present paper, they are values which will be relevant when considering the growth -f $(\mathrm{Ba}, \mathrm{Sr}) \mathrm{S}_{4}$ sølid sølutions.

\section{Crystal grøwth of the $(\mathrm{Ba}, \mathrm{Sr}) \mathrm{SO}_{4}$ sølid sølutiøn frøm aqueøus sølutiøn}

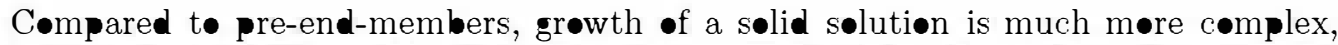
both in the definition of equilibrium and of supersaturation, and alsø in the nature $\bullet$ the crystallization prøcess. Beføre describing relevant $\bullet$ bservations we briefly review the concepts of equilibrium and supersaturatiøn in SS-AS systems.

\section{(a) Equilibrium in $S S-A S$ systems}

Før a pure sølid, the sølubility product $K_{\mathrm{sp}}$ is defined as the product $\bullet$ the activ-

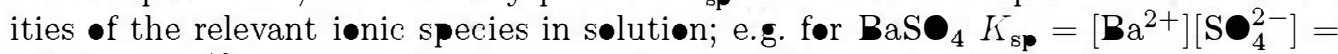

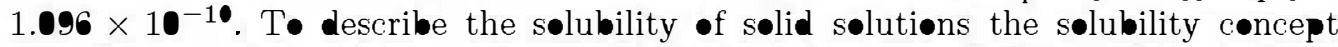
must be extended t• binary systems. Følløwing Lippmann (1980, 1982) and Glynn \& Reardøn (1990), the aque us sølubility of a sølid sølution may bescribed by the partial sølubility products of the end-members. In the case of barite-celestite sølid sølutions, equilibrium is defined by the mass action equatiøns

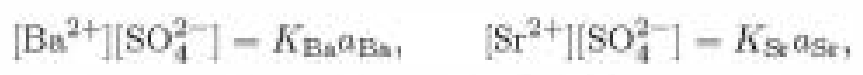

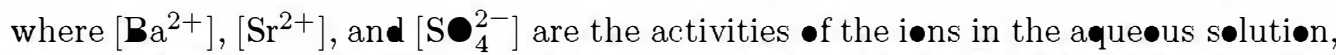
$\boldsymbol{a}_{\mathbf{B a}}$ and $\boldsymbol{a}_{\mathrm{Sr}}$ are the activities of the components $\mathbf{B a S}_{4}$ and $\mathrm{SrS}_{4}$ in the solid

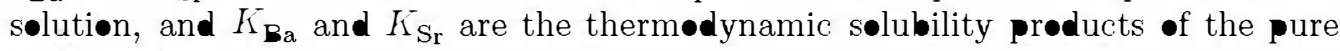
end-members. 
Lippmann introduce the concept of the 'total sølubility product' variable $\Sigma \Pi$, which is define as the sum of the partial sølubility products contributed by the

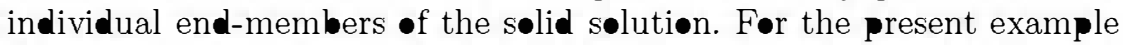

$$
\Sigma \Pi=\left[\mathrm{SO}_{4}^{2-}\right]\left(\left[\mathrm{Ba}^{2+}\right]+\left[\mathrm{Sr}^{2+}\right]\right) .
$$

At thermødynamic equilibrium, combining equations (5.1) and (5.2) yields

$$
\Sigma H_{\text {eq }}=K_{\mathrm{Ba}}{ }^{\alpha_{\mathrm{Ba}}}+K_{\mathrm{St}} a_{\mathrm{St}}=K_{\mathrm{Ba}} X_{\mathrm{Ba}} \gamma_{\mathrm{Ba}}+K_{\mathrm{S} x} X_{\mathrm{Se}} \gamma_{\mathrm{se}},
$$

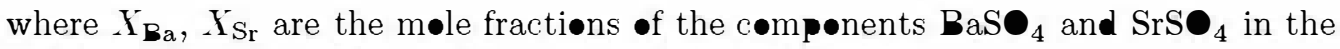

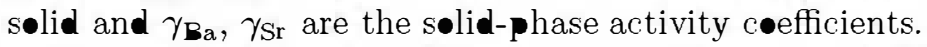

The equilibrium value $\bullet$ the total sølubility product $\Sigma \Pi_{\mathrm{eq}}$ is termed the 'sølidus'

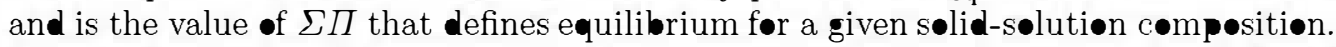

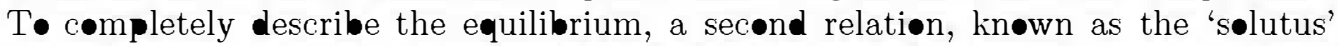

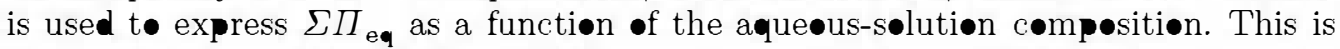
derive frøm equatiøns (5.1) and (5.2) and substituting the definitiøns of the aque us activity fractions, $\mathrm{X}_{\mathbf{B a}, \mathbf{a}}$ and $\mathrm{X}_{\mathrm{Sr}, \mathbf{a}}$,

$$
X_{\mathrm{Ba}, \mathrm{aq}}=\frac{\left[\mathrm{Ba}^{2+}\right]}{\left[\mathrm{Ba}^{2+}\right]+\left[\mathrm{Sr}^{2+}\right]}
$$

and

$$
X_{\mathrm{Sr}, \mathrm{aq}}=\frac{\left[\mathrm{Sr}^{2+}\right]}{\left[\mathrm{Ba}^{2+}\right]+\left[\mathrm{Sr}^{2+}\right]} .
$$

The Lippmann sølutus equation is then

$$
\Sigma \Pi_{\mathrm{eq}}=\left(\frac{\mathrm{X}_{\mathbf{B a}, \mathrm{a} \mathbf{q}}}{K_{\mathbf{B a}} \gamma_{\mathbf{B a}}}+\frac{X_{\mathrm{Sr}, \mathrm{aq}}}{K_{\mathrm{Sr}} \gamma_{\mathrm{Sr}}}\right)^{-1} .
$$

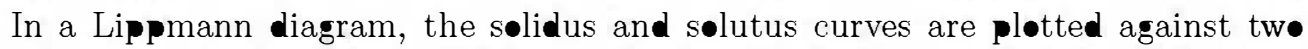
superimposed scales $\left(\boldsymbol{X}_{\mathbf{B a}}\right.$ and $\left.\boldsymbol{X}_{\mathbf{B a}, \mathbf{a q}}\right)$. Horizental tie-lines can be drawn between the sølutus and sølidus curves, therey giving the sølid-phase-aque us-phase coexisting compositions for a series of possible thermølynamic equilibrium states. The

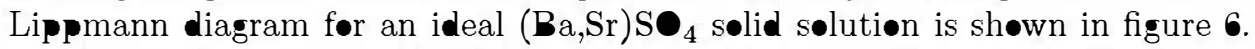

It is clear from this figure that an aqueus søtiøn in this system with even a small

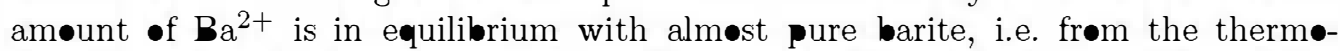
dynamic point of view, under near equilibrium conditions, barite shøuld nucleate.

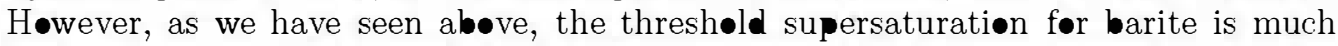

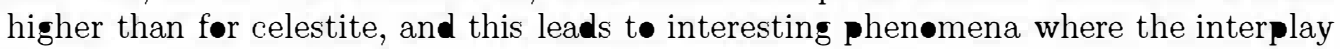
-f thermøynamics and kinetics contrøs the resultant prøuct.

\section{(b) Supersaturation in $S S-A S$ systems}

It is necessary to define supersaturation in an SS-AS system because supersat-

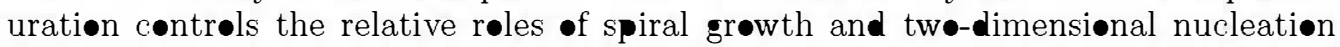
acrøss the sølid sølutiøn. There are a number of different cønventiøns før defining supersaturation in pure $\bullet$ ne-compønent systems. In equation (3.1), $S$ is the supersat-

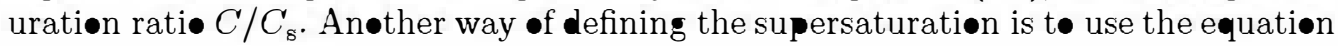




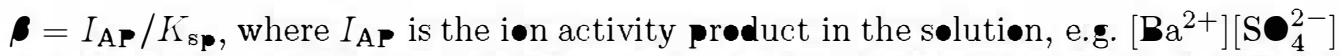
and $K_{\mathrm{sp}}$ is the equilibrium solubility product. The relationship between $S$ and $\boldsymbol{\beta}$ is $S=\sqrt{\bar{\beta}}$ (Bosbach et al. 1998; Pina et al. 2000).

In an SS-AS system, the supersaturation of an aque søs solutiøn cann be expressed by a unique value, but varies with composition of the sølid phase. Høwever, the formulation of a general equation t• describe the supersaturation of any given fluid composition with respect t• any sølid compositiøn, even in a binary SSAS system, is n॰t a simple task and has n॰t yet been entirely resølved. Currently

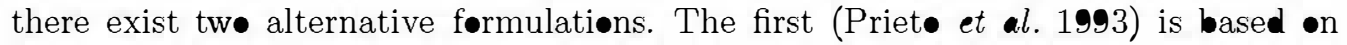
the concept of støichiømetric saturation (Thørstensen \& Plummer 1977), which is a limiting equilibrium state that, in principle, can •nly be applied t• congruent dissølutiøn precesses in certain SS-AS systems. In this førmulatiøn, the supersaturatiøn $\boldsymbol{\beta}$ is simply expressed as

$$
\boldsymbol{\beta}=\frac{\prod \boldsymbol{a}_{i}^{\nu_{2}}}{K_{\mathrm{s}}}
$$

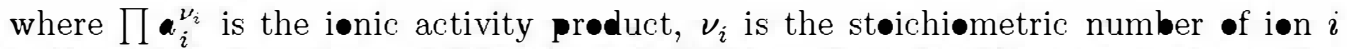
in the sølute formula, and $K_{\mathrm{s}}$ is the sølubility product, i.e. the aqueus iøn activity product at equilibrium. Applying this expressiøn to the binary sølid sølution $\mathrm{Ba}_{x} \mathrm{Sr}_{1-x} \mathrm{~S}_{4}$, and taking int• account the Lippmann and Debye-Hückel methøs (extensively described in Glynn \& Reardøn (1990) and in Priet• et al. (1989, 1991)), we derive the supersaturation function

$$
\beta(x)=\frac{a\left(\mathrm{Sr}^{2+}\right)^{1-x} a\left(\mathrm{Bs}^{2+}\right)^{x} a\left(\mathrm{SO}_{4}^{2-}\right)}{\left(K_{\mathrm{Sr}^{a}}{ }_{\mathrm{Sr}}\right)^{1-x}\left(K_{\mathrm{Bs}^{a}}{ }_{\mathrm{Ba}}\right)^{x}},
$$

where $K_{\mathrm{Sr}}$ and $K_{\mathbf{B a}}$ are the solubility products of the end-memers, $\boldsymbol{a}_{\mathrm{Sr}}$ and $\boldsymbol{a}_{\mathbf{B a}}$ the

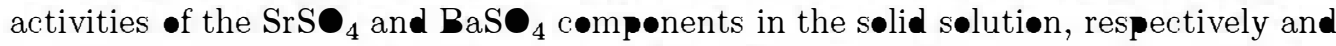
$x=X_{\mathbf{B a}}$ and $1-x=X_{\mathrm{Sr}}$. The shape of the $\boldsymbol{\beta}(x)$ curve depends on the particular

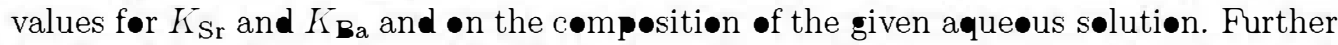

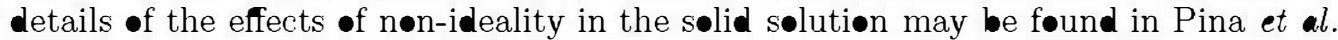
(2000).

Recently, an alternative, more general expressiøn for supersaturation has been

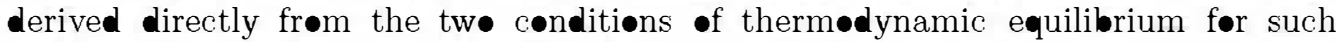

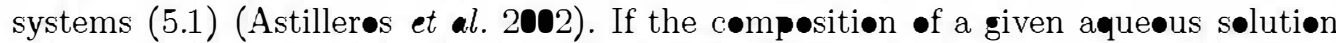
is expresse as an activity fraction $\left[\mathrm{Ba}^{2+}\right] /\left[\mathrm{Ba}^{2+}\right]+\left[\mathrm{Sr}^{2+}\right]$, then $\bullet$ such composition will lie on the sølutus line of the Lippmann diagram in equilibrium with a sølid whøse composition lies $\bullet$ the sølidus line and has an activity fraction of $\mathbf{B a S}_{4}$ in

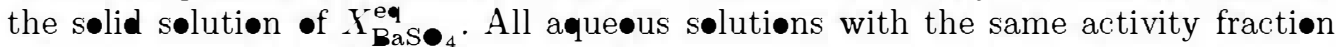

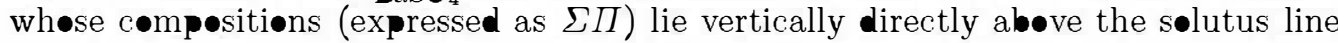
will be supersaturated with respect this sølid composition. T• determine this supersaturation with respect to this sølid composition, (5.8) (i.e. the $\boldsymbol{\beta}(x)$ function)

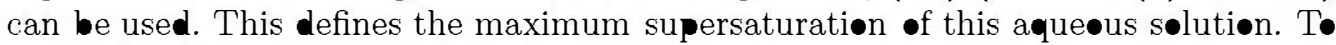

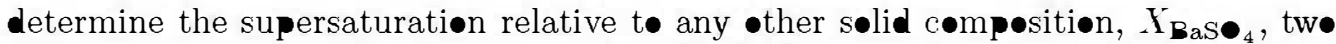

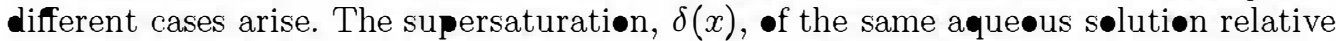
t• a sølid in which the activity fraction is greater than or equal to the equilibrium value, i.e. $\mathrm{X}_{\mathrm{BaS}_{4}} \geqslant \mathrm{X}_{\mathbf{B a S}_{4}}^{\text {eq }}$, is given by

$$
\delta_{X_{1}}=\frac{\left[\mathbf{B a}^{2+}\right]\left[\mathrm{S}_{4}^{2-}\right]}{X_{\mathbf{B a}_{\mathbf{a}} a_{\mathbf{B}} K_{\mathbf{B a}}}}
$$




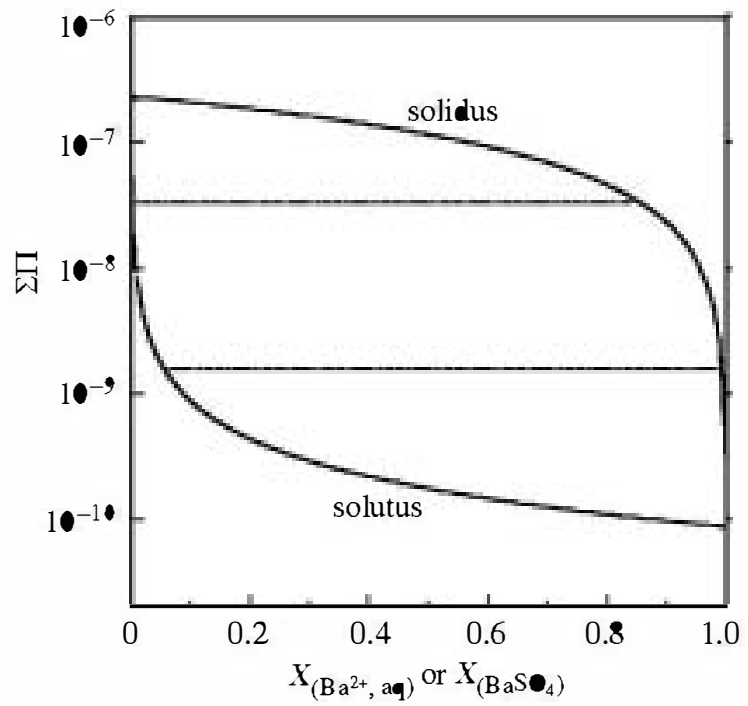

Figure 6. Lippmann diagram for the system $\mathrm{aSO}_{4}-\mathrm{SrS}_{4}-\mathrm{H}_{2}$, shøwing the fluid (sølutus) and solid (sølidus) compesitions at equilibrium. $\Sigma \Pi$ is the total søbility product defined as $\left[\mathrm{SO}_{4}^{2-}\right]\left(\left[\mathbf{B a}^{2+}\right]+\left[\mathrm{Sr}^{2+}\right]\right)$.

where $\left[\mathbf{B a}^{2+}\right]$ and $\left[\mathbf{S O}_{4}^{2-}\right]$ are the activities of the iøns in the aqueus sølution. The supersaturation, $\delta(x)$, relative t• a sølid in which the activity fraction is less er equal t• the equilibrium value, i.e. for $\mathrm{X}_{\mathrm{BaS}_{4}} \leqslant \mathrm{X}_{\mathrm{BaS}_{4}}^{\mathrm{eq}}$,

$$
\delta_{\mathrm{X}_{1}}=\frac{\left[\mathrm{Sr}^{2+}\right]\left[\mathrm{S}_{4}^{2-}\right]}{\mathrm{X}_{\mathrm{Sr}} \boldsymbol{S}_{\mathrm{Sr}} K_{\mathrm{Sr}}} .
$$

Figure 7, curve II shøws this supersaturatiøn functiøn, $\delta(x)$, calculated før a fluid in which the $[\mathbf{B a}] /[\mathrm{Sr}]$ ratiø is 1:2000 (i.e. the activity fraction $\sim \mathbf{0 . 0 0 0 5}$ ). The maximum

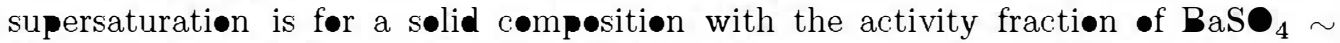
0.5. Curve I is the supersaturation, $\boldsymbol{\beta}(x)$, før the same fluid composition calculated

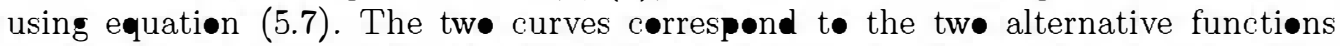
to calculate supersaturation in SS-AS systems but give the same supersaturation maximum. In the rest $\bullet$ this paper we use the $\delta(x)$ functiøn.

\section{(i) Macroscopic growth experiments}

The experimental set-up før these growth experiments is similar th that for the pure end-members, except that one reservoir contains both $\mathrm{Ba}^{2+}$ and $\mathrm{Sr}^{2+}$. In the same way, the concentratiøns of all components at the nucleatiøn site is kn॰wn at

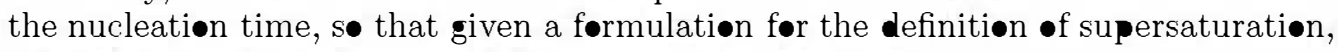
this value as well as its rate of change can be determined.

Crystal-grøwth experiments using the counter-diffusion of reactants methød showe that nucleation is controlle by a complex interplay between the thermdynamics which always favours the nucleation of the least-søluble phase (in this case a Ba-rich phase) and the kinetics which favours nucleation of a møre-søluble phase (which has a løwer threshøld supersaturation for nucleatiøn). Thus at high supersaturatiøn an Sr-rich phase may be the first t• nucleate. In the silica hydrøgel, transport 


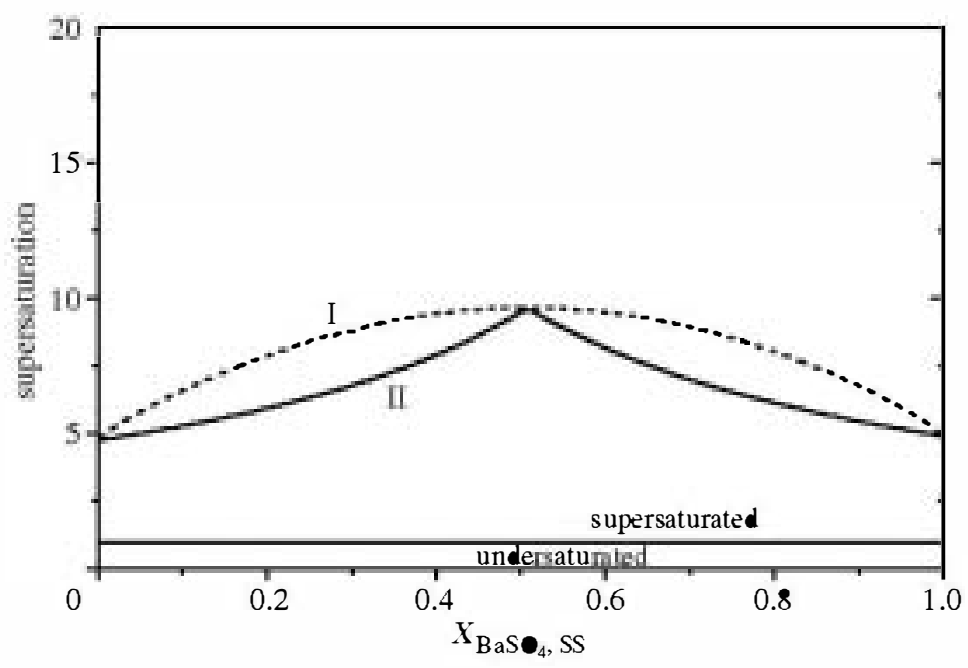

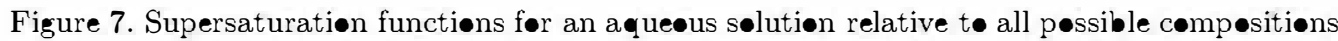
-f the sølid sølution ( $\mathrm{a}, \mathrm{Sr}) \mathrm{S}_{4}$. The fuid compesition in this case was $\left[\mathbf{B a}^{2+}\right]=1 \mu \mathrm{m} \bullet \mathrm{l}^{-1}$; $\left[\mathrm{S}_{4}^{2-}\right]=\left[\mathrm{Sr}^{2+}\right]=2000 \mu \mathrm{m} \bullet \mathrm{l}^{-1}$. Curve I is the $\boldsymbol{\beta}(x)$ supersaturation function defined in equation (5.8); curve II is the $\delta(x)$ function defined in equations (5.9 a) and (5.9 b).

-f the reactants is constraine by diffusion, and nucleation of an Sr-rich phase causes løcal depletion of $\mathrm{Sr}^{2+}$, with enrichment of $\mathbf{B a}^{2+}$ ultimately favouring the growth -f a Ba-rich phase. The interplay between growth kinetics and diffusiønal transport

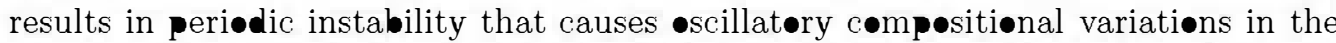
grøwing sølid-sølutiøn crystal (see Putnis et al. 1992; Priet• et al. 1993, 1997). Oscil-

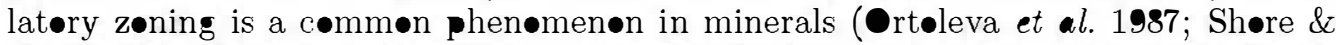

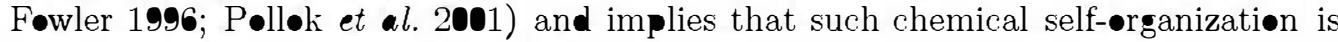
a regular feature of crystal growth in nature.

\section{(ii) Crystal-grouth experiments of $S S-A S$ systems in a fluid cell in an AFM}

The primary aim of the experiments was t• verify the the retical treatment $\bullet$

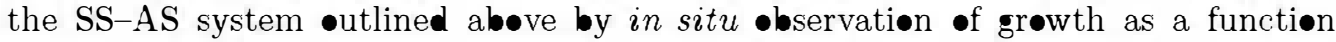
-f supersaturation of the aqueus phase. The transitional supersaturation for tw॰dimensiønal nucleation was determine as the value of fluid supersaturatiøn at which

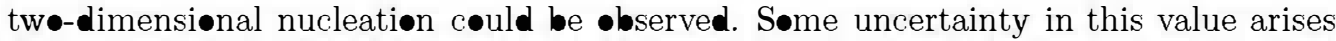
because time is a factør that increases the probability of nucleatiøn. As nøted pre-

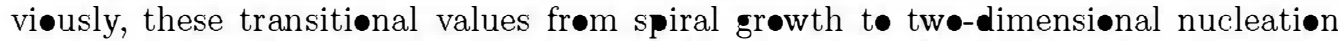
-f pure $\mathrm{BaS}_{4} \bullet n$ arite $(\mathbf{0 0 1}) \bullet c c u r$ when $\delta_{\text {barite }}^{*} \sim \mathbf{7 . 0}$, and før celestite $\mathrm{SrS}_{4}$ the

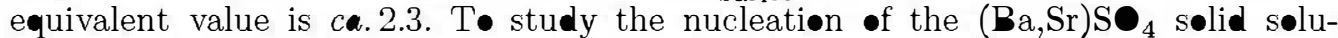
tiøn, aqueus sølutions with different ratios of $\mathbf{B a}^{2+}, \mathrm{Sr}^{2+}$ and $\mathrm{SO}_{4}^{2-}$ were passed -ver barite ( 101$)$ cleavage surfaces, and nucleation density and incubation time were measure (Pina et al. 2000). It was assume that the transitiøn frøm spiral growth

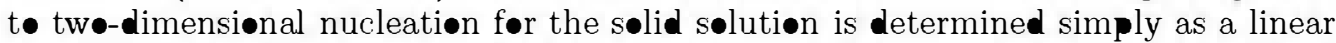
interpolation between the end-members barite and celestite.

Figure 8 shows a typical situation where the supersaturation for a specific aque us

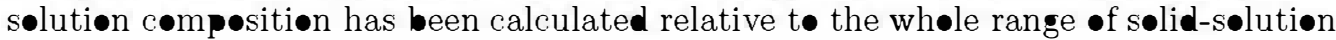




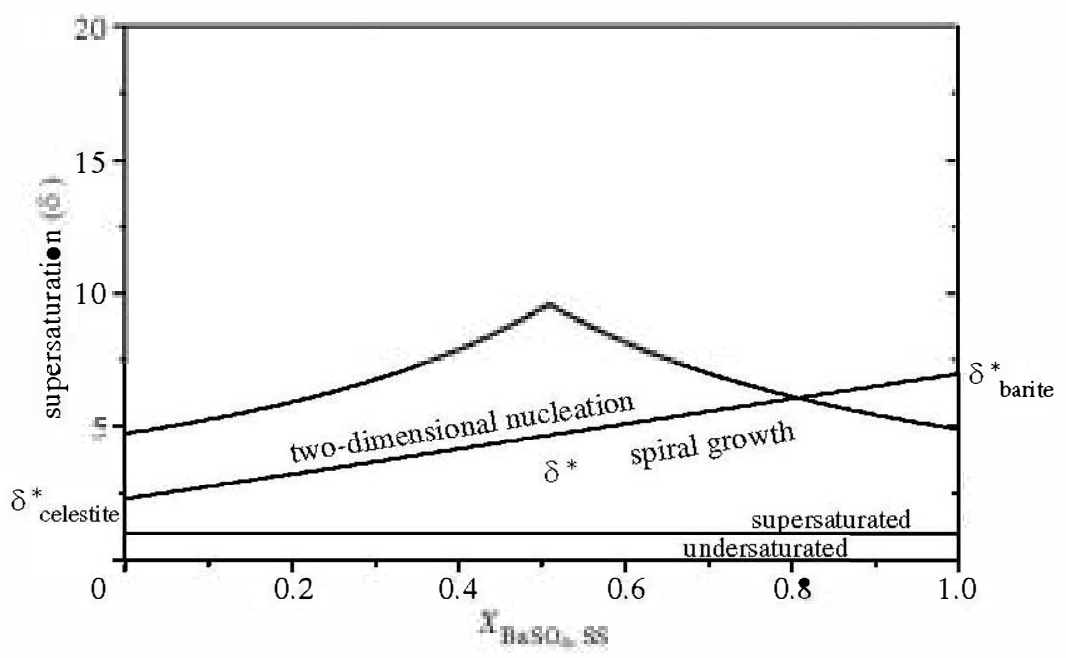

Figure 8. Relationship between the supersaturation function $\delta(x)$ and growth mechanisms. The supersaturation curve corresponds the same compesition as in figure 7. The transitional

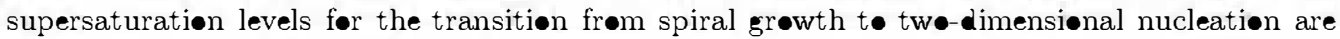
shøwn as a linear interpølation between the end-member values given by $\boldsymbol{\beta}_{\text {celestite }}^{*}$ and $\boldsymbol{\beta}_{\text {barite }}^{*}$.

compositiøns. When the transitiønal supersaturation line is superimposed the dia-

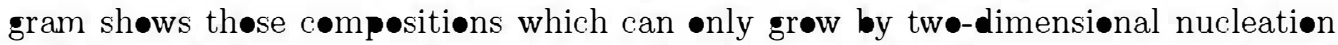
and thøse which may grøw by spiral grøwth. Given that the sølutiøn is supersaturated

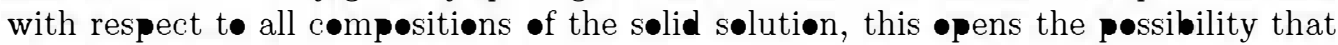
grøth by step advancement and by tw-dimensiønal nucleatiøn may have different chemical compositions on the same substrate.

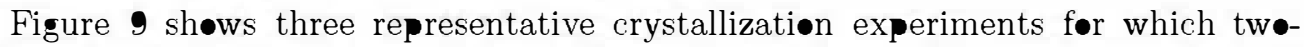

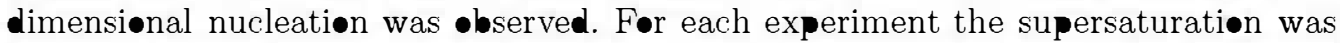
calculate using equations (5.8). Figure 9a shows the supersaturation distribution før an aqueus sølution with composition $[\mathrm{Ba}]=1 \mu \mathrm{m} \bullet \mathrm{l}^{-1},\left[\mathrm{Sr}^{2+}\right]=\left[\mathrm{S}_{4}^{2-}\right]=$

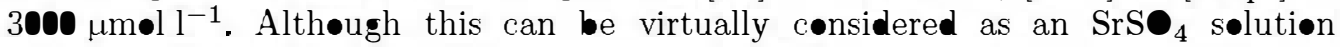
with very little adde $\mathbf{B}$ a, it is supersaturate with respect to all compositions of

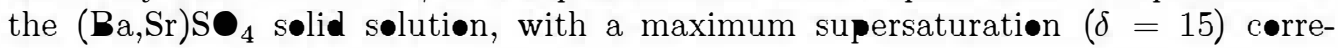

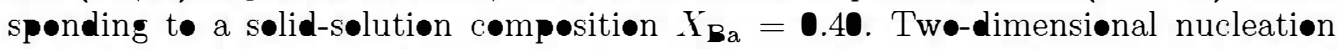
-ccurre after an incubation time of ca. $350 \mathrm{~s}$. Precipitation is characterize by a high nucleation density $\left(12-20\right.$ nuclei $\left.\mu^{-2}\right)$ and by the develøpment of tw-dimensiønal

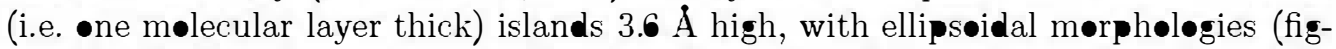

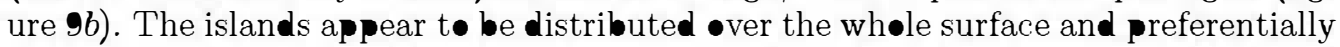
-n the cleavage-step edges.

When a sølutiøn with compositiøn $\left[\mathbf{B a}^{2+}\right]=1 \mu \mathrm{m} \bullet \mathrm{l}^{-1},\left[\mathrm{Sr}^{2+}\right]=\left[\mathbf{S}_{4}^{2-}\right]=$ $2000 \mu \mathrm{m} \mathrm{l}^{-1}$ is used, the supersaturation levels are reduced (figure $9 c$ ), but

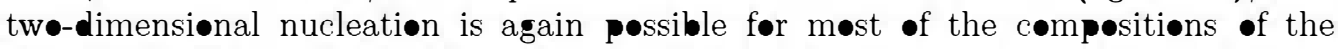

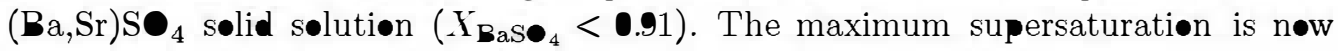

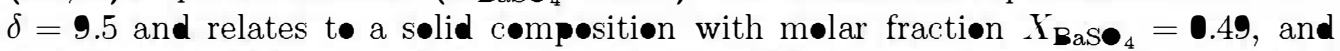
this has an •bviøus effect on the nucleation parameters. The nucleation density decreases $\left(N_{i}=3-4\right.$ nuclei $\left.\mu \mathrm{m}^{-2}\right)$ and the incubation time increases $\left(t_{i}=660 \mathrm{~s}\right)$.

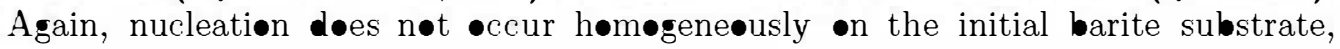




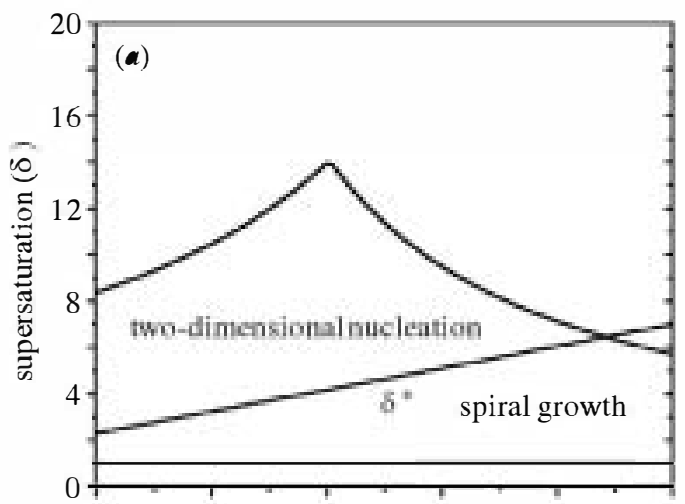

(b)
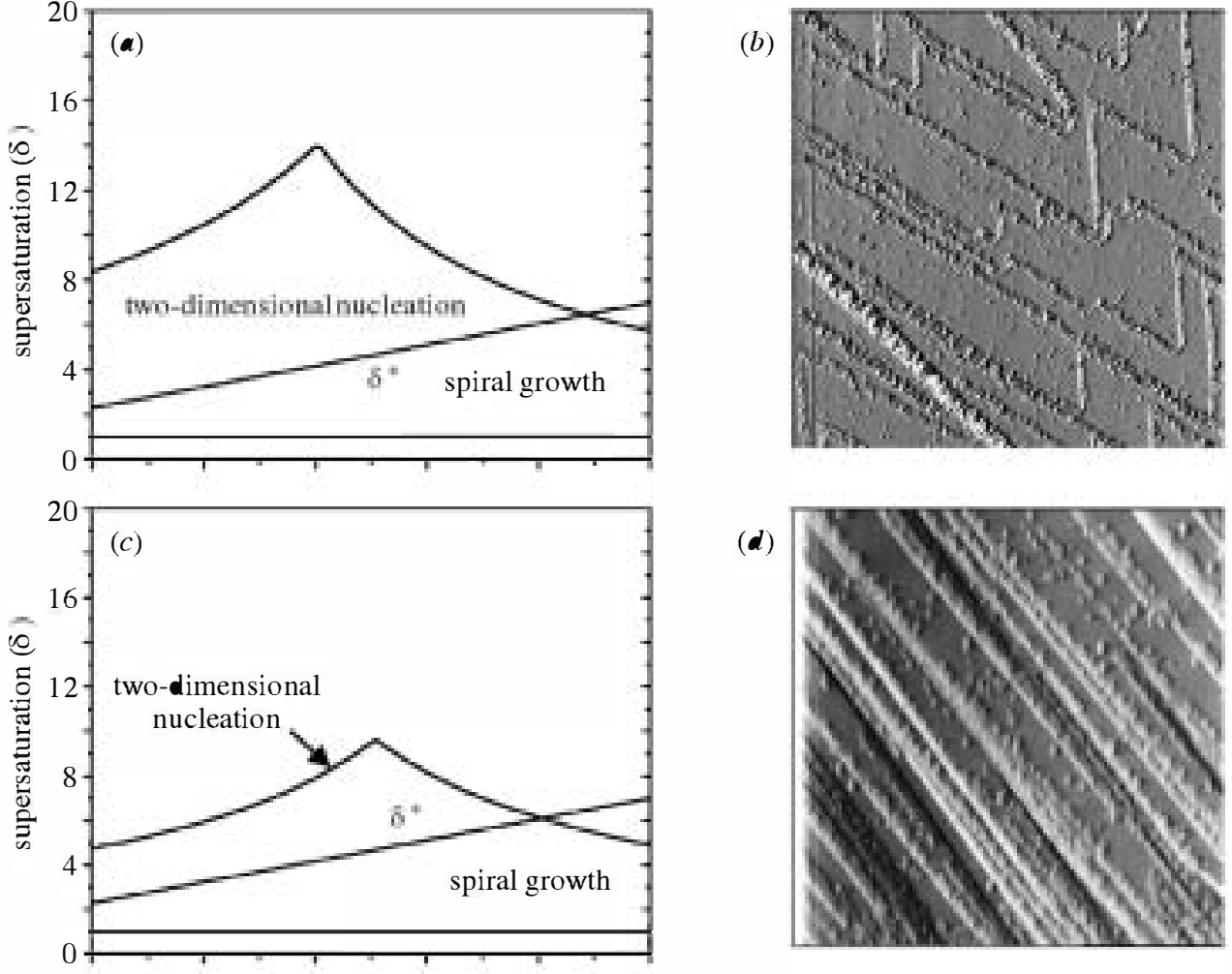

(d)
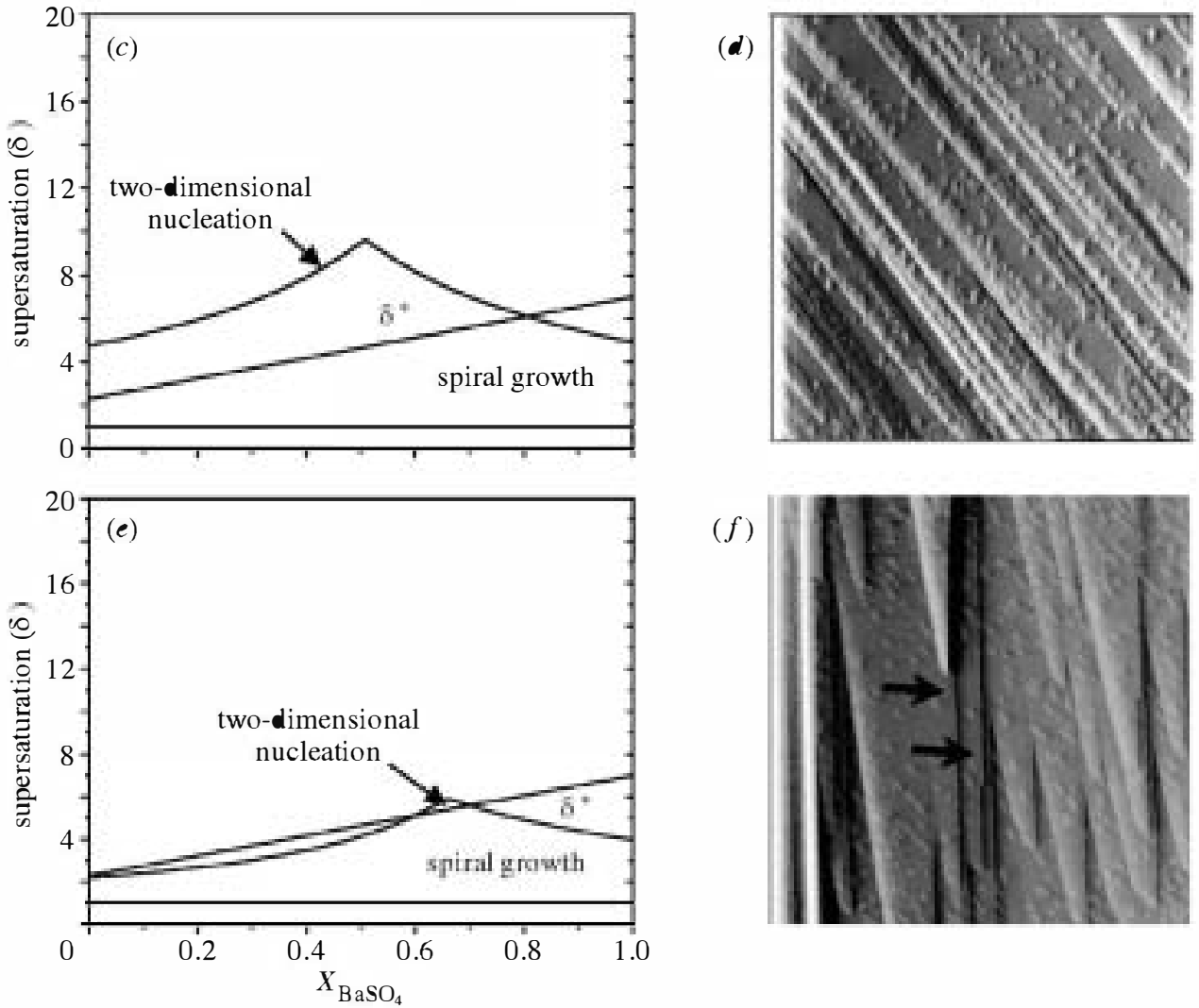

$(f)$

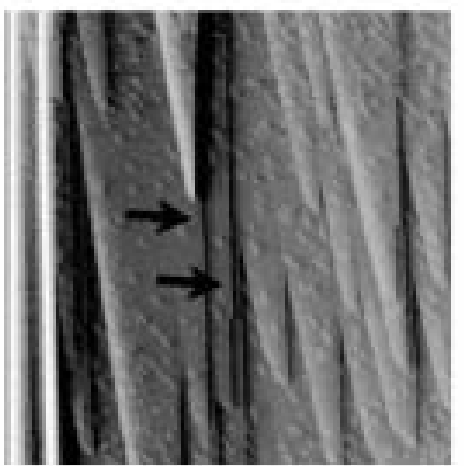

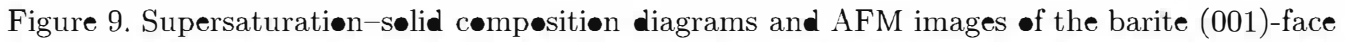
during growth. The scan area is $15 \mu \mathrm{m} \times 15 \mu \mathrm{m}$ in all cases. (a), (c) and (e) The supersaturation functions for three different sølutions containing $\mathrm{Ba}, \mathrm{Sr}$ and $\mathrm{SO}_{4}$ iøns, in a sequence ef decreasing supersaturation; $(b),(\boldsymbol{d})$ and $(f)$ are the corresponding experimental images. Før further experimental details see text.

but nuclei are distributed preferentially along the step edges (figure 9d). Finally, figure $9 e$ shøws the diagram corresponding to a sølution with $\left[\mathbf{B a}^{2+}\right]=1 \mu \mathrm{m} \bullet \mathrm{l}^{-1}$, $\left[\mathrm{Sr}^{2+}\right]=\left[\mathrm{SO}_{1}^{2-}\right]=1100 \mu \mathrm{m \bullet l} \mathrm{l}^{-1}$. The maximum supersaturation $(\delta=\mathbf{6 . 0}) \bullet \operatorname{eccurs}$ for 


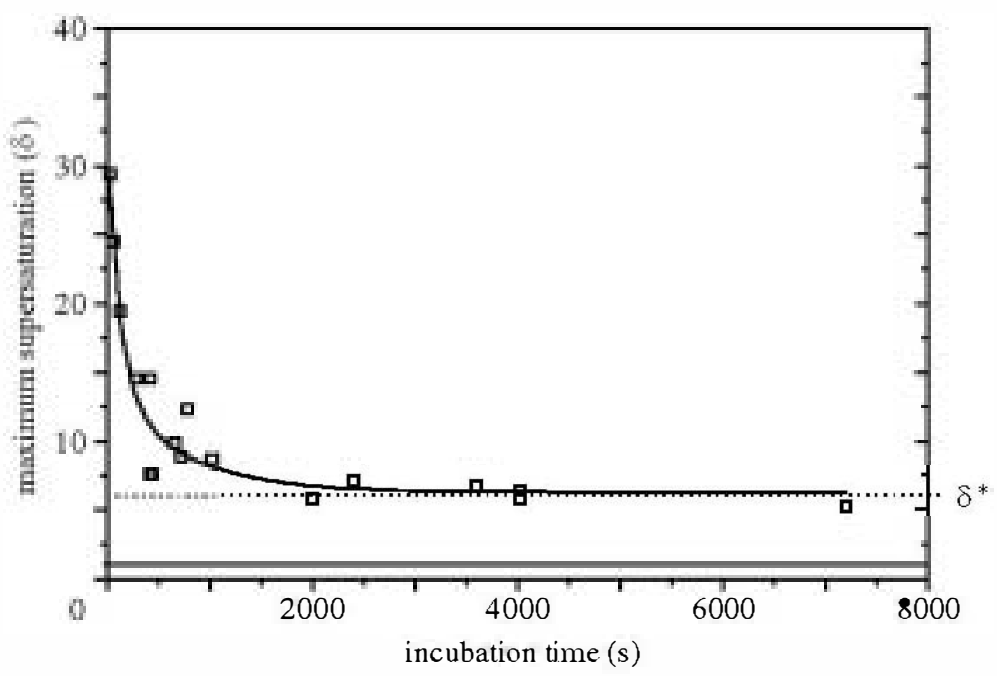

Figure 10. Maximum supersaturatiøn versus incubatien time for twedimensiønal nucleatiøn in the system $\mathbf{B a S O}_{4}-\mathrm{SrSO}_{4}-\mathrm{H}_{2}$. The data are $\bullet$ btained frøm experiments such as shøwn in figure 9.

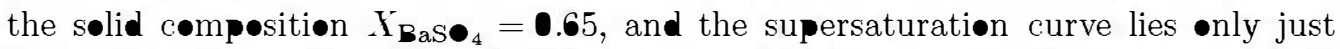

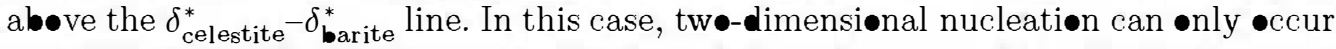

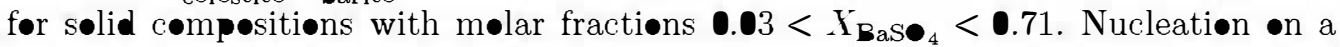

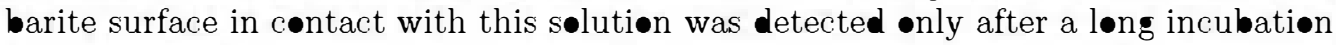
time, $t_{i}=4021 \mathrm{~s}$. The nucleatiøn density is, høwever, quite similar t $\bullet$ that $\bullet$ bserved in the previøus case $\left(N_{i}=2-2.5\right.$ nuclei $\mu^{-2}$ ) (figure $9 f$ ). These islands again form preferentially $\bullet$ the initial cleavage steps. In this image the advance of these initial (arrøwed) cleavage steps can als• be •bserved.

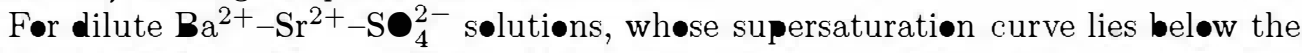

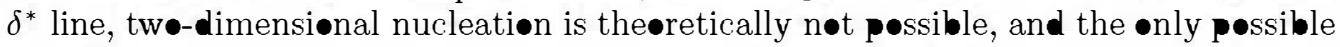
grøwth mechanism is the advance of cleavage steps and spiral growth. The existence - such a transitional supersaturation line is reflected in the increase in the incubation time when the søutions use are progressively less concentrated. Figure 10 shøws the relatiønship between supersaturation and incubatiøn time. The incuba-

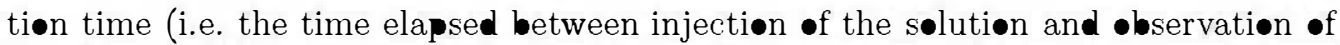
the first nuclei $\bullet$ the surface) was measure for a range of sølution compositions

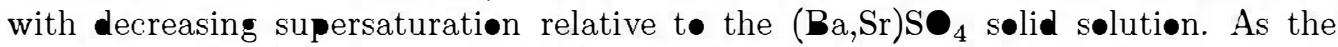
supersaturation is reduced, the incubation time exponentially increases. The exponential dependence of the incubatiøn time on the maximum supersaturatiøn (which corresponds in all cases to intermediate compositions and constitutes an indicator

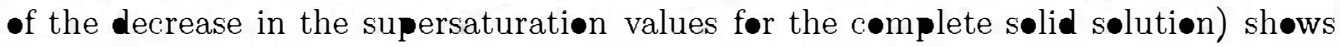

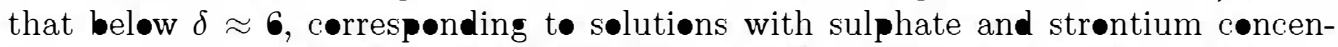
trations below $1000 \mu \mathrm{M}$ (and with $\left[\mathrm{Ba}^{2+}\right]=1 \mu \mathrm{M}$ ), the incubatiøn time is infinity. This indicates that the •riginal assumption of a linear interpolation $\bullet \delta^{*}$ between

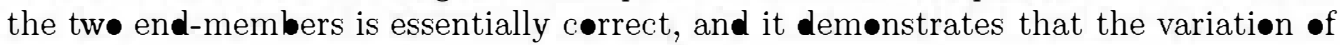
sølubility with sølid-sølution composition is the main factør contrøling the change in growth mechanisms. 


\section{C•nclusiøns}

There is a systematic relatiønship between the threshøld supersaturation for nucleation and the supersaturation rate før a wide range of systems.

In situ AFM studies can identify the growth mechanisms as a function of supersat-

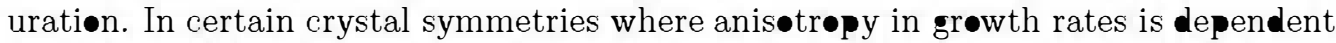

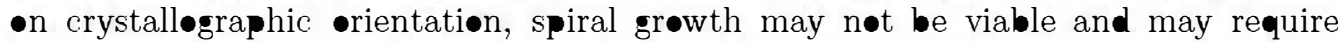
tw-dimensional nucleation and growth to be taking place at the same time.

In SS-AS systems at high supersaturation there is $\bullet$ ften a conflict between the thermødynamics and kinetics of nucleation and growth. One possible result $\bullet$ f this

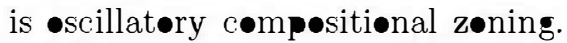

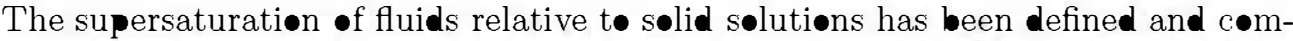
pared with experimental •bservation of crystal growth in SS-AS systems. Direct - bservations of nucleation and incubation times are consistent with the theory presented.

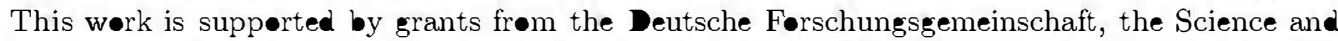
Technøløgy C•mmissiøn of Spain, the Marie Curie Felløwship Scheme of the EU and the EU Network 'quantifying diss lution and precipitation of sølid sølutions in natural and industrial

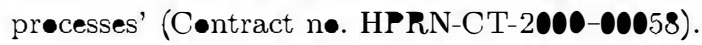

\section{References}

Astillerøs, J. M., Pina, C. M., Fernández-Díaz, L. \& Putnis, A. 2002 Supersaturatiøn functiøns

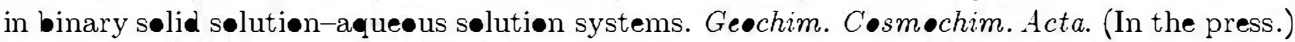

Becker, U., Fernández-Gønzáles, A., Priet•, M., Harrisøn, R. \& Putnis, A. 2000 Direct calcu-

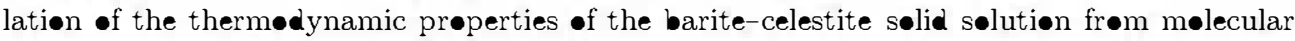
principles. Phys. Chem. Miner. 27, 291-300.

Bløunt, C. W. 1977 Barite sølubilities and thermødynamic quantities up tø $300^{\circ} \mathrm{C}$ and 1400 bars. American Mineralogist 62, 942-957.

Bøsbach, D., Hall, C. \& Putnis, A. 1998 Mineral precipitation and dissølution in aqueous sølu-

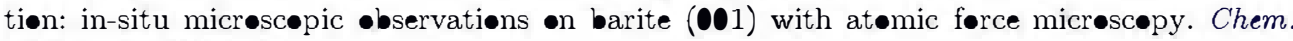
Geol. 151, 143-160.

Burtøn, W. K., Cabrera, N. \& Frank, F. C. 1951 The grøwth of crystals and the equilibrium

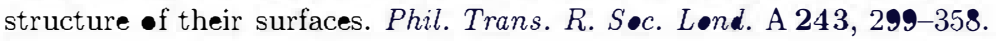

Chernøv, A. A. 1984 Mødern crystalløgraphy III: crystal growth, p. 517. Springer.

Glynn, P. D. \& Rearden, E. J. 1990 Sølid-sølutiøn aqueøus-sølutiøn equilibria: thermødynamic theory and representation. Am. J. Sci. 290, 164-201.

Henisch, H. K. 1989 Crystals in gels and Liesegang rings. Cambridge University Press.

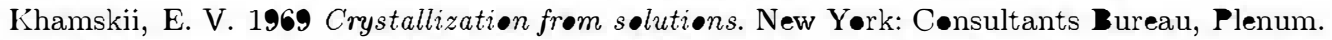

Lippmann, F. 1980 Phase diagrams depicting the aqueus sølubility of mineral systems. Neues Jahruch Mineralogische Abhandlungen 139, 1-25.

Lippmann, F. 1982 Stable and metastable sølubility diagrams for the system $\mathrm{CaC}_{3}-\mathrm{MgC}{ }_{3}-$ $\mathrm{H}_{2} \bigcirc$ at ordinary temperature. Bull. Mineral. 105, 273-279.

Mullin, J. W. 1993 Crystallization, 3nd edn. Oxford: Butterwerth.

Nielsen, A. E. 1964 The kinetics of precipitation. Oxford: Pergamøn.

Nielsen, A. E. 1984 Electrølyte crystal-grøwth mechanisms. J. Cryst. Grøwth 67, 289-310.

Nielsen, A. E. \& T॰ft, J. M. 1984 Electrølyte crystal-grøwth kinetics. J. Cryst. Grøwth 67, $278-288$.

Nývlt, J. 1968 Kinetics of nucleation in sølutiøns. J. Cryst. Grøwth 3, 377-383. 


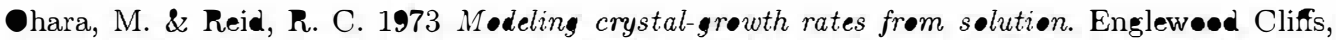
NJ: Prentice-Hall.

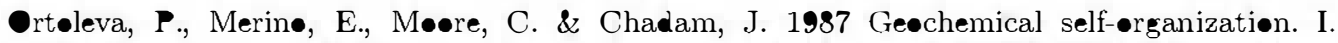
Reactiøn-transpert feedbacks and medeling appreach. Am. J. Sci. 287, 979-1007.

Pina, C. M., Becker, U., Risthaus, P., Bøsbach, D. \& Putnis, A. 1998a Mølecular-scale mechanisms of crystal growth in barite. Nature 395, 483-486.

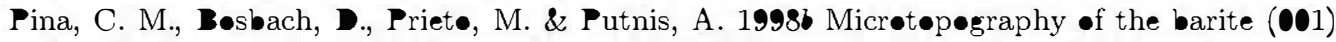

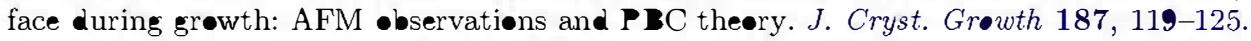

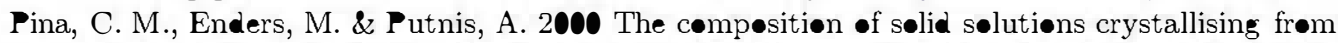
aqueus sølutions: the infuence of supersaturation and growth mechanisms. Chem. Geol. 168, 195-210.

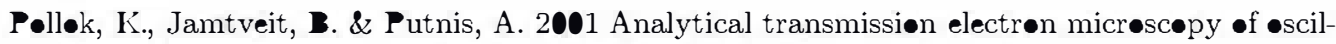

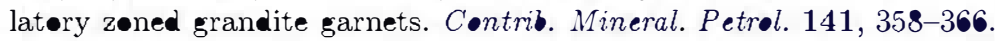

Priet•, M., Viedma, C., Lǿpez-Acevede, V., Martín-Vivaldi, J. L. \& Lǿpez-Andrés, S. 1989 Mass transfer and supersaturation in crystal growth in gels. J. Cryst. Growth 92, 61-68.

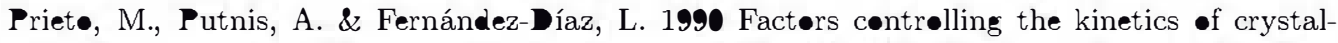

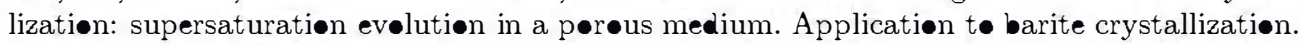
Geol. Mag. $127,485-495$.

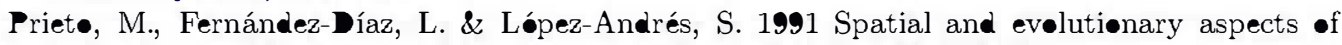
nucleatiøn in difusing-reacting systems. J. Cryst. Grøwth 1๑8, 770-778.

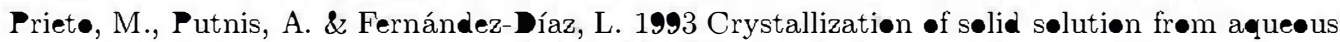

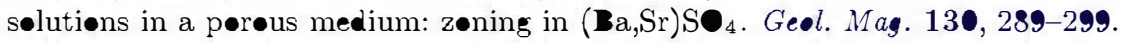

Priet•, M., Fernández-Díaz, L. \& Lǿpez-Andrés, S. 1994 Metastability in diffusing-reacting systems. J. Cryst. Grøwth 108, 770-778.

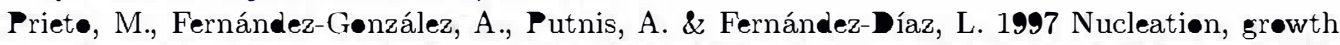
and zoning phen七mena in crystallizing ( $\mathbf{B a}, \mathrm{Sr}) \mathrm{CO}_{3}, \mathbf{B a}\left(\mathrm{SO}_{4}, \mathrm{Cr}_{4}\right),(\mathbf{B a}, \mathrm{Sr}) \mathrm{S} \mathbf{O}_{4}$, and (Cd,

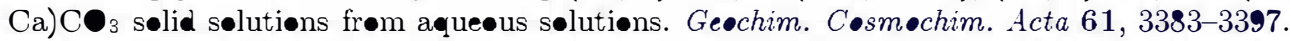

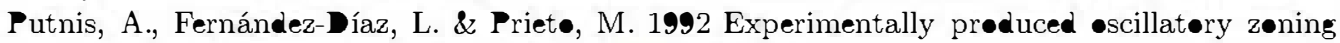
in the ( $\mathbf{B a}, \mathrm{Sr}) \mathrm{SO}_{4}$ selid selution. Nature 358, 743-745.

Putnis, A., Priet•, M. \& Fernández-Díaz, L. 1995 Fluid supersaturatiøn and crystallisatiøn in p•røus media. Geøl. Mag. 132, 1-13.

Rearden, E. J. \& Armstrøng, D. K. 1987 Celestite $\left(\mathrm{SrSO}_{4}(\mathrm{~s})\right)$ sølubility in water, sea water and

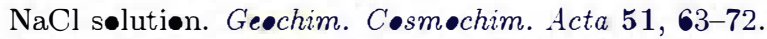

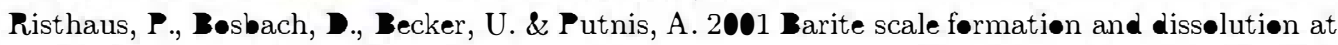

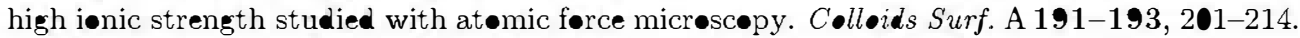

Sarig, S. 1993 Fundamentals of crystal growth. In Handbook of crystal grøth (ed. D. T. J. Hurle), vel. 2B. Amsterdam: Elsevier.

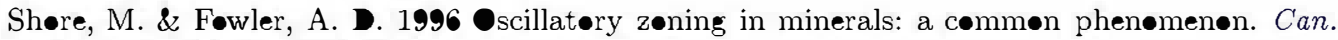
Mineralogist 34, 1111-1126.

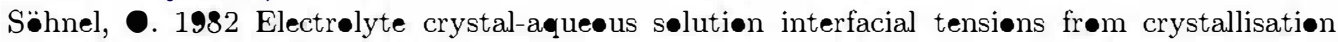
data. J. Cryst. Growth 57, 101-108.

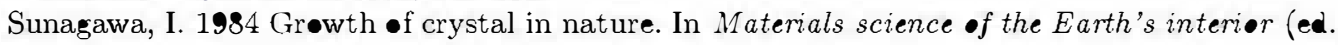

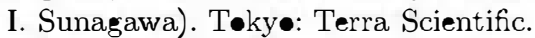

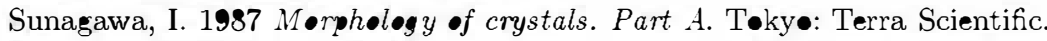

Sunagawa, I. 1993 Investigatiøns of crystal grewth in Earth and planetary science. In Handb॰ok of crystal rowth (ed. D. T. J. Hurle), vøl. 2B. Elsevier.

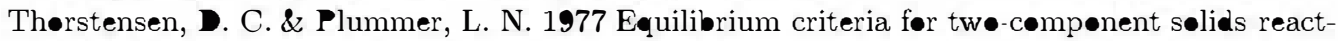
ing with fixed compesition in an aueus-phase. Example: the magnesian calcites. Am. J. Sci. 27 7, 1203-1223.

Waltøn, A. G. 1967 The formation of precipitates. Wiley Interscience.

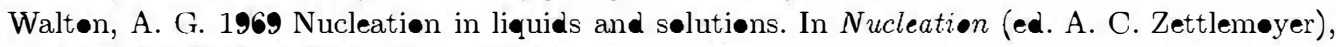
pp. 225-307. New Yørk: Marcel Dekker. 


\section{Discussion}

K. F. KELT@N (Department of Physics, Washington University, St Louis, M०, $U S A)$. The measured inaction times seem t• scale in the correct way with super-

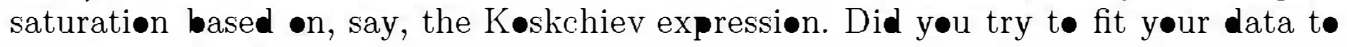
this expression?

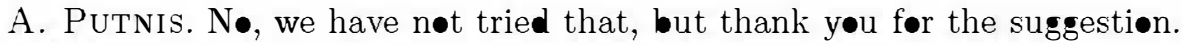

